\title{
LEVEL II SCOUR ANALYSIS FOR BRIDGE 23 (WNDSTH00070023) on TOWN HIGHWAY 7, crossing MILL BROOK, WINDSOR, VERMONT
}

Open-File Report 98-079

Prepared in cooperation with

VERMONT AGENCY OF TRANSPORTATION

and

FEDERAL HIGHWAY ADMINISTRATION

U.S. Department of the Interior

U.S. Geological Survey

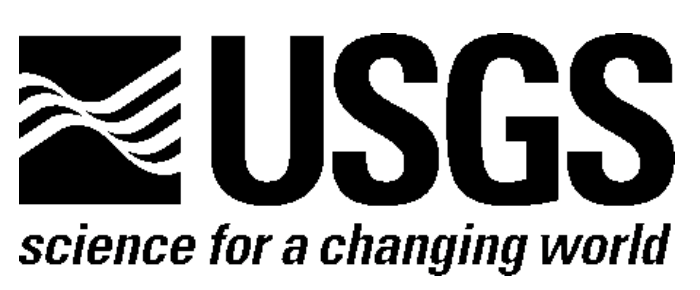




\section{LEVEL II SCOUR ANALYSIS FOR BRIDGE 23 (WNDSTH00070023) on TOWN HIGHWAY 7, crossing MILL BROOK, WINDSOR, VERMONT \\ By RONDA L. BURNS}

U.S. Geological Survey Open-File Report 98-079

Prepared in cooperation with

VERMONT AGENCY OF TRANSPORTATION

and

FEDERAL HIGHWAY ADMINISTRATION 


\title{
U.S. DEPARTMENT OF THE INTERIOR BRUCE BABBITT, Secretary
}

\author{
U.S. GEOLOGICAL SURVEY
}

Thomas J. Casadevall, Acting Director

For additional information write to:

District Chief

U.S. Geological Survey 361 Commerce Way

Pembroke, NH 03275-3718
Copies of this report may be purchased from:

U.S. Geological Survey

Branch of Information Services

Open-File Reports Unit

Box 25286

Denver, CO 80225-0286 


\section{CONTENTS}

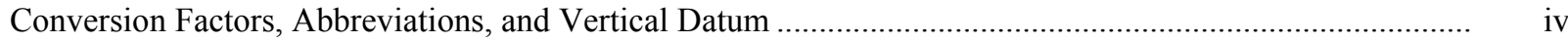

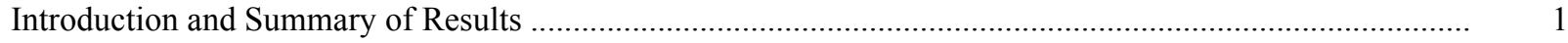

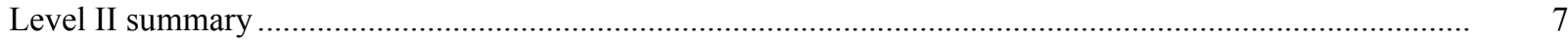

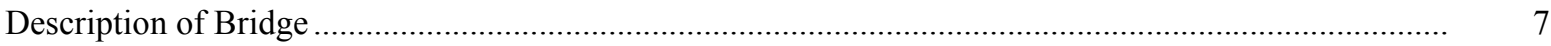

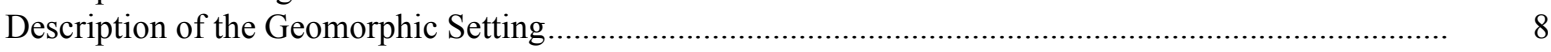

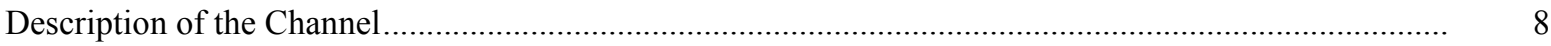

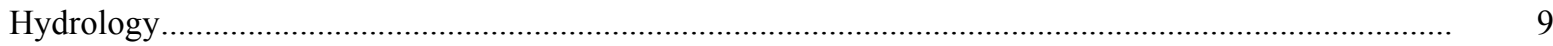

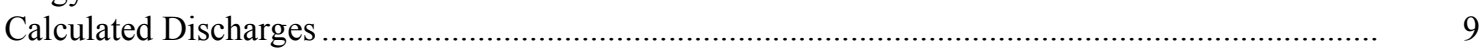

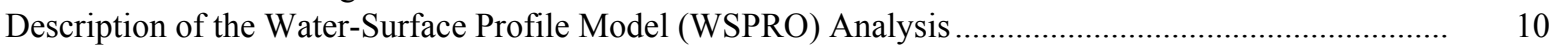

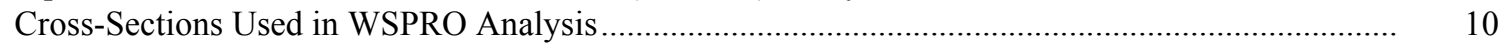

Data and Assumptions Used in WSPRO Model ........................................................................ 11

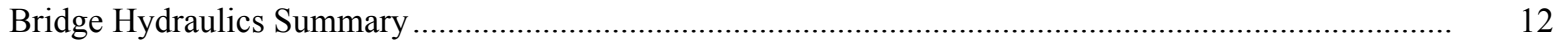

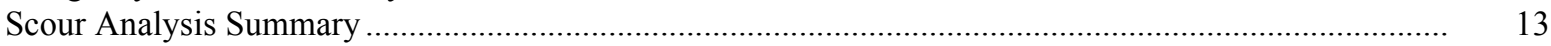

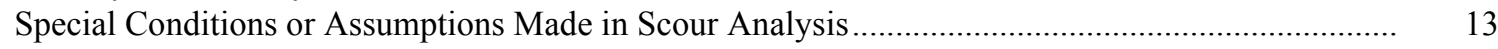

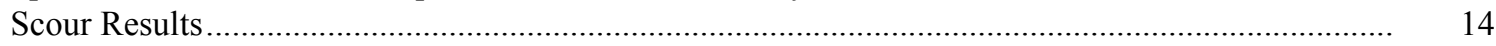

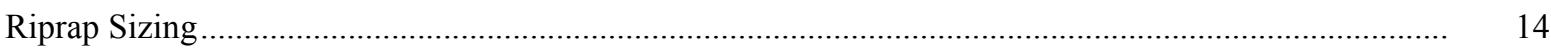

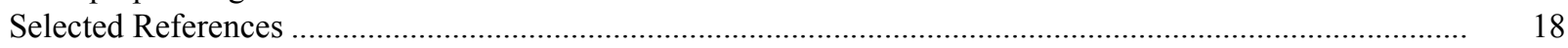

Appendices:

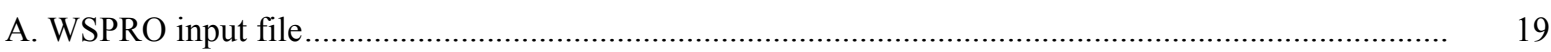

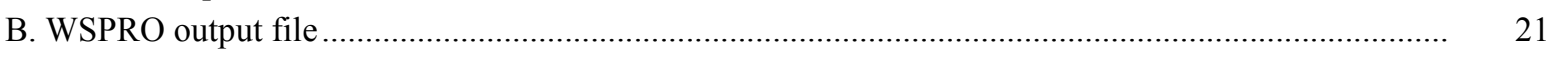

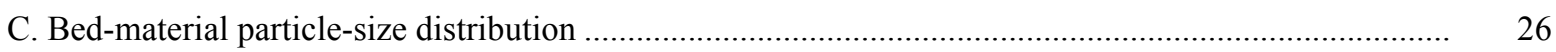

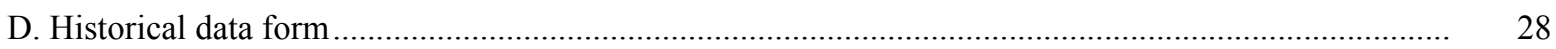

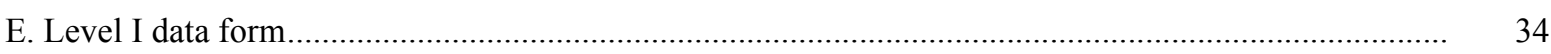

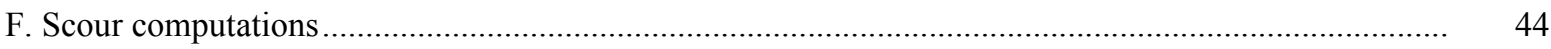

\section{FIGURES}

1. Map showing location of study area on USGS 1:25,000 scale map

2. Map showing location of study area on Vermont Agency of Transportation town highway map

3. Structure WNDSTH00070023 viewed from upstream (July 29, 1996).

4. Downstream channel viewed from structure WNDSTH00070023 (July 29, 1996)

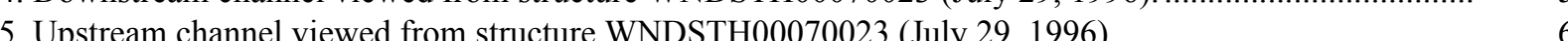

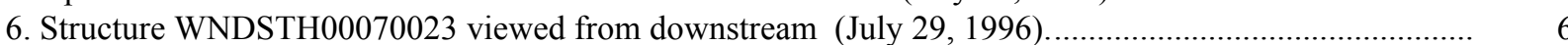

7. Water-surface profiles for the 100- and 500-year discharges at structure WNDSTH00070023 on Town Highway 7, crossing Mill Brook, Windsor, Vermont.

8. Scour elevations for the 100- and 500-year discharges at structure

WNDSTH00070023 on Town Highway 7, crossing Mill Brook,

Windsor, Vermont.

\section{TABLES}

1. Remaining footing/pile depth at abutments for the 100-year discharge at structure

WNDSTH00070023 on Town Highway 7, crossing Mill Brook,

Windsor, Vermont....

2. Remaining footing/pile depth at abutments for the 500-year discharge at structure

WNDSTH00070023 on Town Highway 7, crossing Mill Brook,

Windsor, Vermont. 


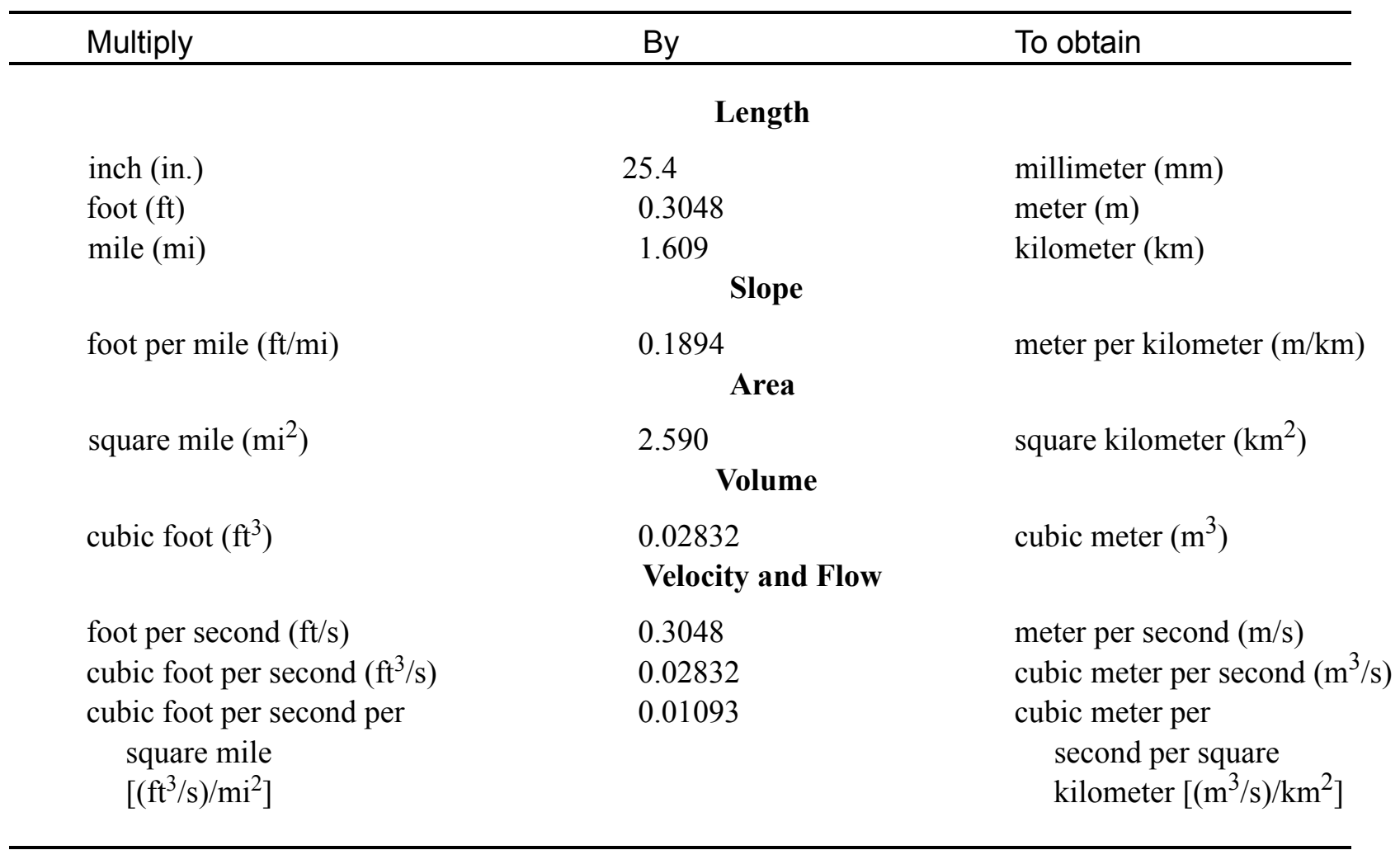

\section{OTHER ABBREVIATIONS}

$\begin{array}{lrlr}\text { BF } & \begin{array}{r}\text { bank full } \\ \text { cfs }\end{array} & \text { LWW } & \text { left wingwall } \\ \mathrm{D}_{50} & \text { median feet per second } & \text { Max } & \text { maximum } \\ \mathrm{DS} & \text { main channel } \\ \mathrm{elev} & \text { downstream } & \text { RAB } & \text { elevation } \\ \mathrm{f} / \mathrm{p} & \text { RABUT } & \text { right abutment } \\ \mathrm{ft} & \text { flood plain } & \text { RB } & \text { face of right abutment } \\ \mathrm{ft} / \mathrm{ft} & \text { square feet } & \text { ROB } & \text { right bank } \\ \text { FEMA } & \text { feet per foot } & \text { RWW } & \text { right overbank } \\ \text { FHWA } & \text { Federal Emergency Management Agency } & \text { TH } & \text { right wingwall } \\ \text { JCT } & \text { Federal Highway Administration } & \text { UB } & \text { town highway } \\ \text { LAB } & \text { junction } & \text { US } & \text { under bridge } \\ \text { LABUT } & \text { left abutment } & \text { USGS } & \text { upstream } \\ \text { LB } & \text { face of left abutment } & \text { VTAOT } & \text { Vermont Agency of Transportation } \\ \text { LOB } & \text { left bank } & \text { WSPRO } & \text { water-surface profile model } \\ & \text { left overbank } & \text { yr } & \text { year }\end{array}$

In this report, the words "right" and "left" refer to directions that would be reported by an observer facing downstream. Sea level: In this report, "sea level" refers to the National Geodetic Vertical Datum of 1929-- a geodetic datum derived from a general adjustment of the first-order level nets of the United States and Canada, formerly called Sea Level Datum of 1929.

In the appendices, the above abbreviations may be combined. For example, USLB would represent upstream left bank. 


\title{
LEVEL II SCOUR ANALYSIS FOR BRIDGE 23 (WNDSTH00070023) ON TOWN HIGHWAY 7, CROSSING MILL BROOK, WINDSOR, VERMONT
}

\author{
By Ronda L. Burns
}

\section{INTRODUCTION AND SUMMARY OF RESULTS}

This report provides the results of a detailed Level II analysis of scour potential at structure WNDSTH00070023 on Town Highway 7 crossing Mill Brook, Windsor, Vermont (figures 1-8). A Level II study is a basic engineering analysis of the site, including a quantitative analysis of stream stability and scour (Federal Highway Administration, 1993). Results of a Level I scour investigation also are included in appendix E of this report. A Level I investigation provides a qualitative geomorphic characterization of the study site. Information on the bridge, gleaned from Vermont Agency of Transportation (VTAOT) files, was compiled prior to conducting Level I and Level II analyses and is found in appendix D.

The site is in the New England Upland section of the New England physiographic province in east-central Vermont. The $37.9-\mathrm{mi}^{2}$ drainage area is in a predominantly rural and forested basin. In the vicinity of the study site, the surface cover is forest.

In the study area, Mill Brook has an incised, straight channel with a slope of approximately $0.01 \mathrm{ft} / \mathrm{ft}$, an average channel top width of $79 \mathrm{ft}$ and an average bank height of $12 \mathrm{ft}$. The channel bed material ranges from sand to boulder with a median grain size $\left(\mathrm{D}_{50}\right)$ of 64.6 $\mathrm{mm}(0.212 \mathrm{ft})$. The geomorphic assessment at the time of the Level I and Level II site visit on July 29,1996 , indicated that the reach was laterally unstable. There are cut-banks upstream and downstream of the bridge.

The Town Highway 7 crossing of Mill Brook is a 54-ft-long, two-lane bridge consisting of one 51-foot steel-beam span (Vermont Agency of Transportation, written communication, March 23, 1995). The opening length of the structure parallel to the bridge face is $48.7 \mathrm{ft}$. The bridge is supported by vertical, concrete abutments with wingwalls. The channel is skewed approximately 10 degrees to the opening while the opening-skew-to-roadway is zero degrees. 
Channel scour $1.0 \mathrm{ft}$ deeper than the mean thalweg depth was observed along the downstream right side of the channel during the Level I assessment. Also, the footings of the left and right abutments and left wingwalls are exposed and the upstream end of the left abutment footing is undermined. The only scour protection measure at the site was type-3 stone fill (less than 48 inches diameter) along the upstream and downstream right bank and wingwalls. Additional details describing conditions at the site are included in the Level II Summary and appendices D and E.

Scour depths and recommended rock rip-rap sizes were computed using the general guidelines described in Hydraulic Engineering Circular 18 (Richardson and Davis, 1995) for the 100- and 500-year discharges. Total scour at a highway crossing is comprised of three components: 1) long-term streambed degradation; 2) contraction scour (due to accelerated flow caused by a reduction in flow area at a bridge) and; 3 ) local scour (caused by accelerated flow around piers and abutments). Total scour is the sum of the three components. Equations are available to compute depths for contraction and local scour and a summary of the results of these computations follows.

Contraction scour for all modelled flows ranged from 3.0 to $3.9 \mathrm{ft}$. The worst-case contraction scour occurred at the 500-year discharge. Abutment scour ranged from 11.0 to $14.3 \mathrm{ft}$. The worst-case abutment scour occurred at the 500-year discharge. Additional information on scour depths and depths to armoring are included in the section titled "Scour Results". Scoured-streambed elevations, based on the calculated scour depths, are presented in tables 1 and 2. A cross-section of the scour computed at the bridge is presented in figure 8. Scour depths were calculated assuming an infinite depth of erosive material and a homogeneous particle-size distribution.

It is generally accepted that the Froehlich equation (abutment scour) gives "excessively conservative estimates of scour depths" (Richardson and Davis, 1995, p. 46). Usually, computed scour depths are evaluated in combination with other information including (but not limited to) historical performance during flood events, the geomorphic stability assessment, existing scour protection measures, and the results of the hydraulic analyses. Therefore, scour depths adopted by VTAOT may differ from the computed values documented herein. 


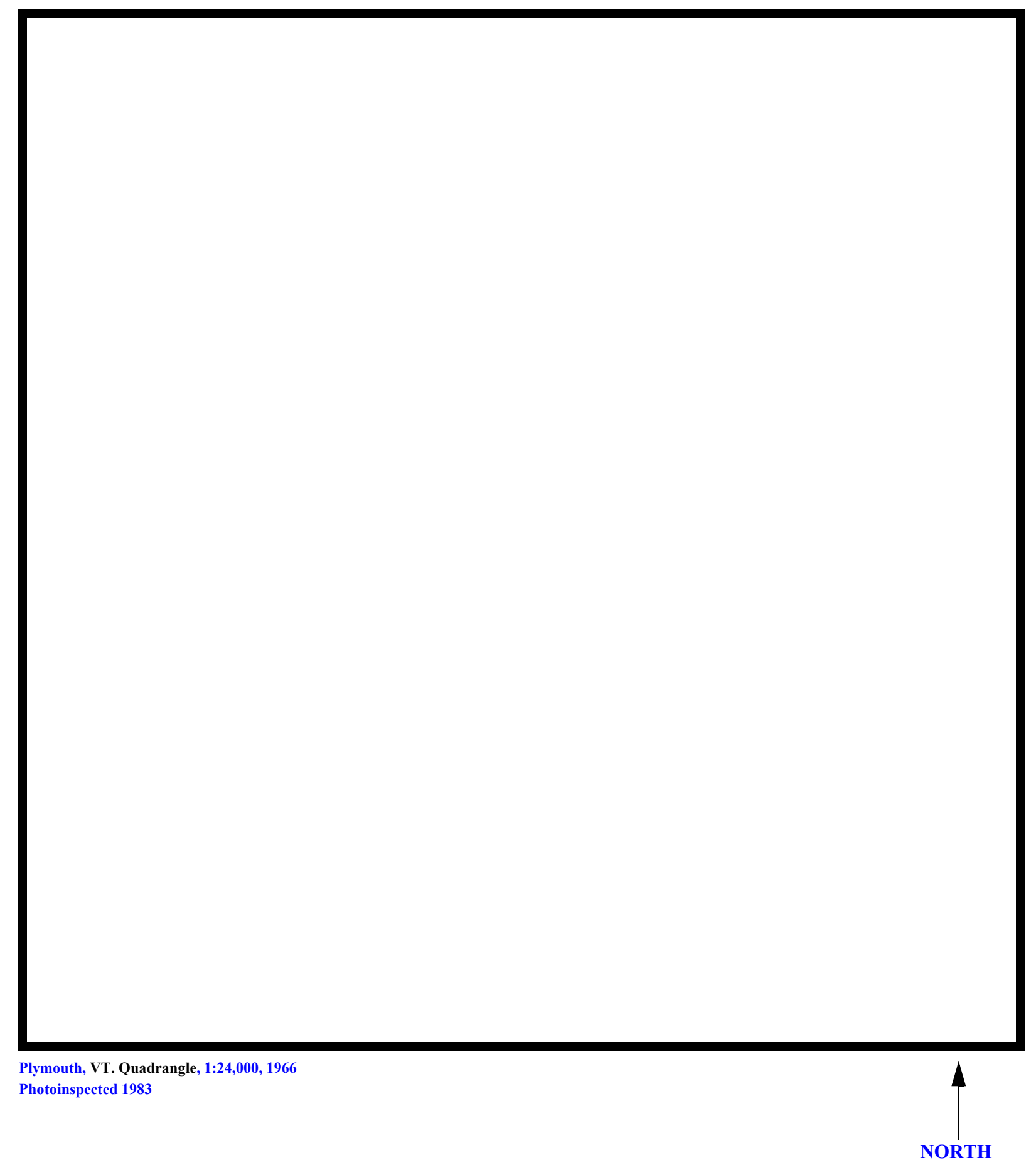

Figure 1. Location of study area on USGS 1:24,000 scale map. 
Figure 2. Location of study area on Vermont Agency of Transportation town highway map. 

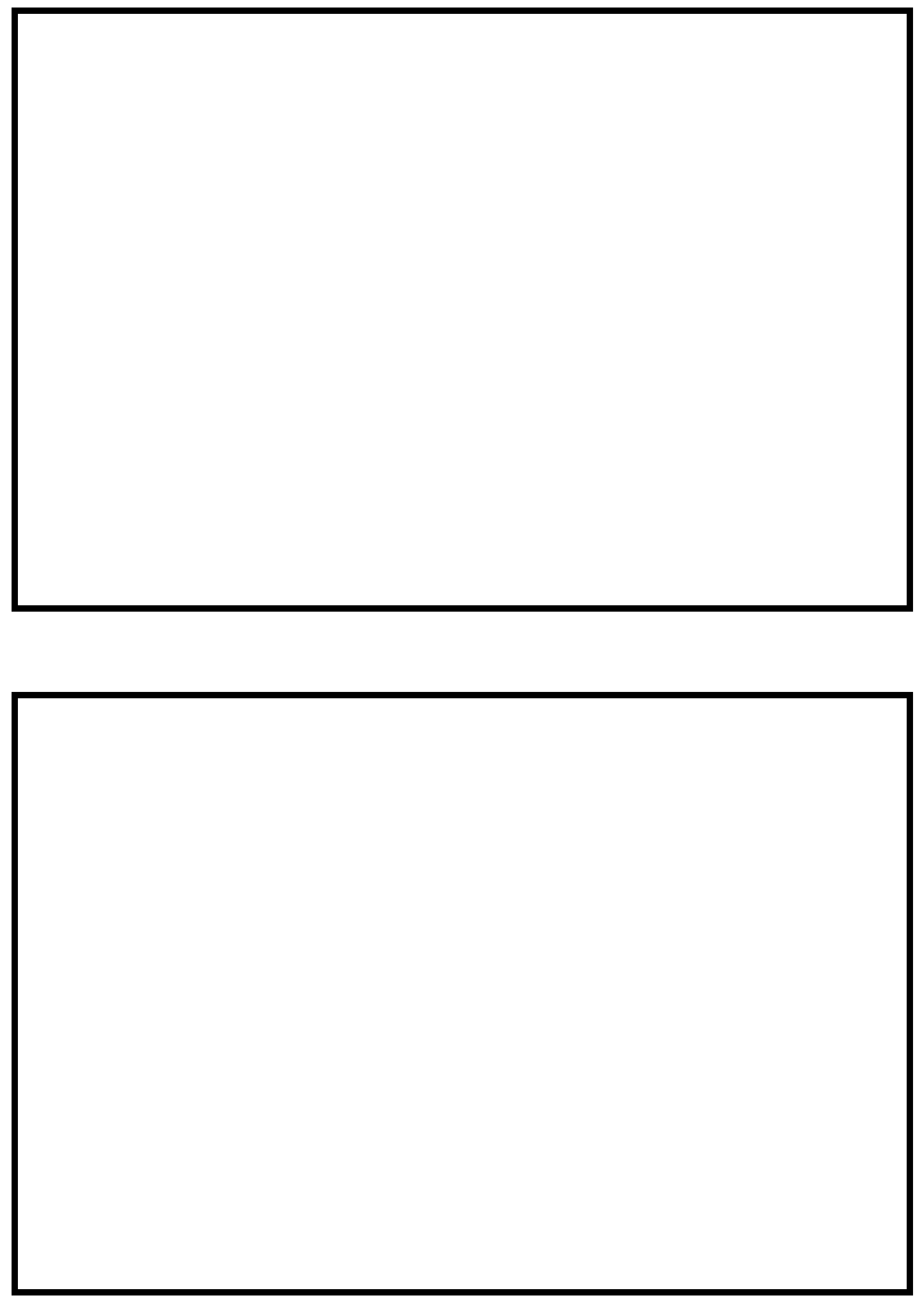

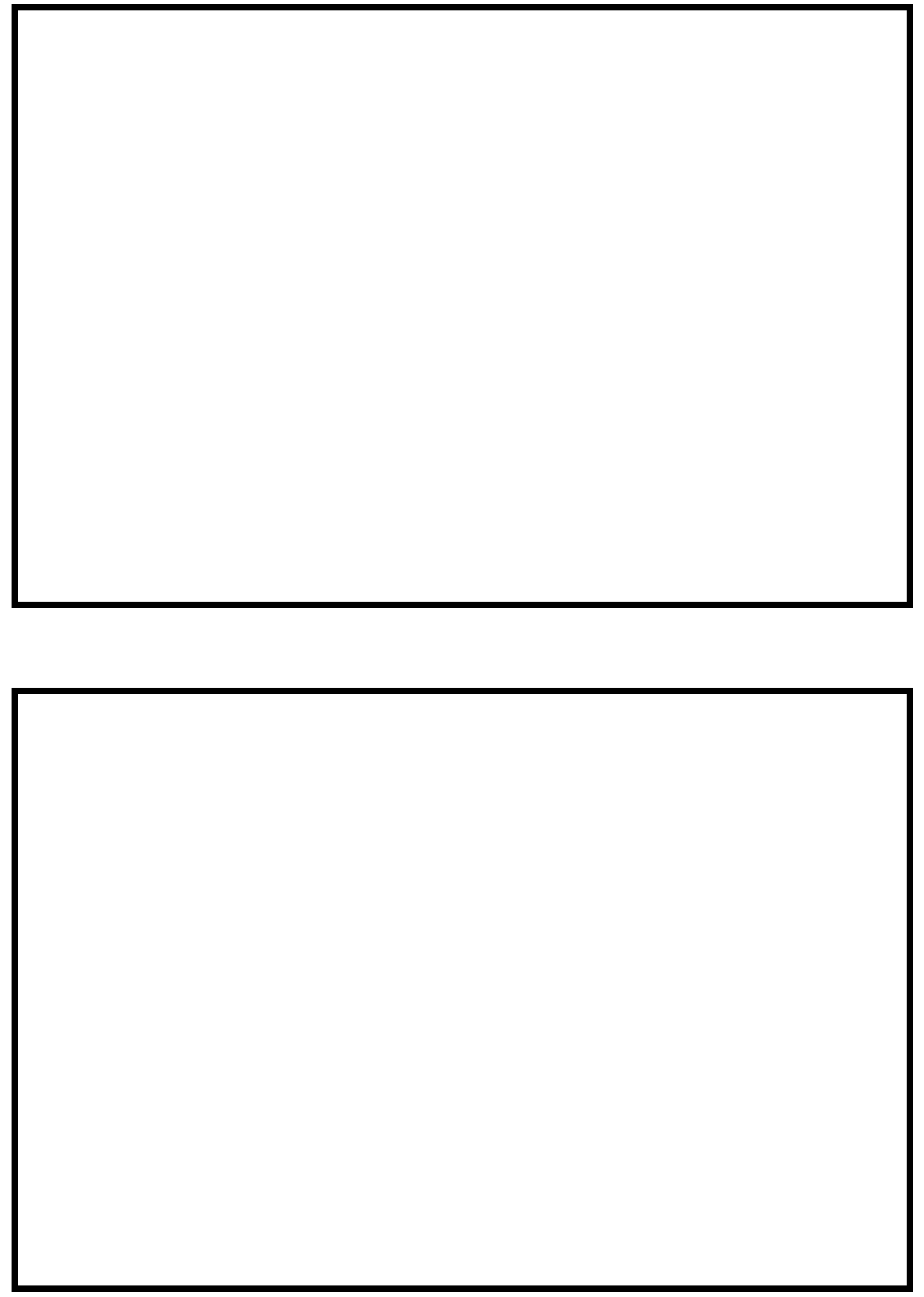


\section{LEVEL II SUMMARY}

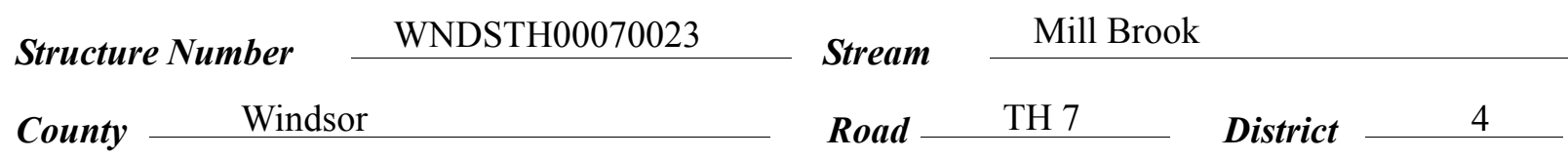

\section{Description of Bridge}

Bridge length $\frac{54}{} \boldsymbol{f t} \quad$ Bridge width $\frac{19.7}{f t} \quad$ Max span length $\stackrel{51}{ } f$ Alignment of bridge to road (on curve or straight)

Abutment type Vertical, concrete

\section{Stone fill on abutment?}

\section{Embankment type} Straight

$$
\text { Sloping }
$$

nansuintion af atan a fill No stone fill on the abutments. The only protection at this site was type-3, along the entire base length of the upstream and downstream right wingwalls.

Abutments and wingwalls are concrete. The footings of the left and right abutments and left

$$
\text { upstream and downstream wingwalls are exposed and }
$$

the upstream end of the left abutment footing is undermined.

Yes

$10 \quad$ No

Is bridge skewed to flood flow according to. 'survey?

Angle

Debris accumulation on bridge at time of Level I or Level II site visit:

$$
\begin{array}{cc}
\text { Date af insnortion } & \begin{array}{c}
\text { Percent of nhannal } \\
0
\end{array} \\
\hline
\end{array}
$$

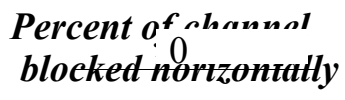$$
96
$$

Level I

Level II

0

Moderate. There is some debris caught on the upstream banks.
Percent o: $7 / 29 /$
blocked verticalty

0

None as of 7/29/96.

Potential for debris

Doscriho any, foaturos noar ar at tho hridoo that mav, affort flou, (includo ahsorvation dato) 


\section{Description of the Geomorphic Setting}

General topography The channel is located within a low relief valley with a steep valley wall on the right.

Geomorphic conditions at bridge site: downstream (DS), upstream (US)

Date of inspection $\quad 7 / 29 / 96$

DS left: $\quad$ Steep channel bank to a moderately sloped overbank

DS right: $\quad$ Steep valley wall

US left: $\quad$ Steep channel bank to a moderately sloped overbank

US right: $\quad$ Steep valley wall

\section{Description of the Channel}

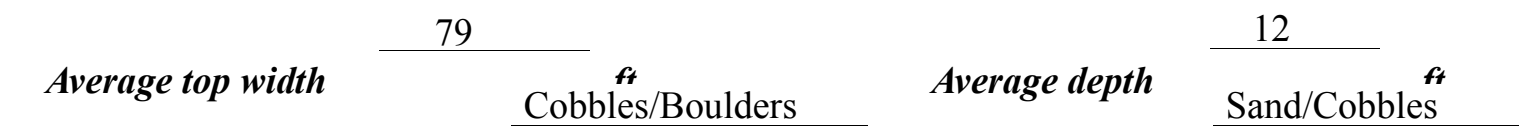

Predominant bed material

Bank material Straight but laterally

unstable with semi-alluvial channel boundaries.

$7 / 29 / 96$

Vegetative co 1 Trees and bruš

DS left: $\quad$ Trees and brush

DS right: $\quad$ Trees and brush

US left: $\quad$ Trees and brush

US right: $\quad$ No

Do banks appear stable? There are cut-banks, upstream and downstream of the bridge

date of observatton.

The assessment of

7/29/96 noted low flow conditions are influenced by a mid-channel bar in the upstream reach Describe any obstructions in channel and date of observation.

which causes the flow to impact the upstream left bank. 


\section{Hydrology}

Drainage area $\stackrel{37.9}{\boldsymbol{m i}^{2}}$

Percentage of drainage area in physiographic provinces: (approximate)

Physiographic province/section New England/New England Upland
Percent of drainage area 100
Is drainage area considered rural or urban?
Rural None.
urbanization: None.
Describe any significant

Is there a USGS gage on the stream of interest?

No

USGS gage description

USGS gage number

Gage drainage area $\mathrm{mi}^{2}$

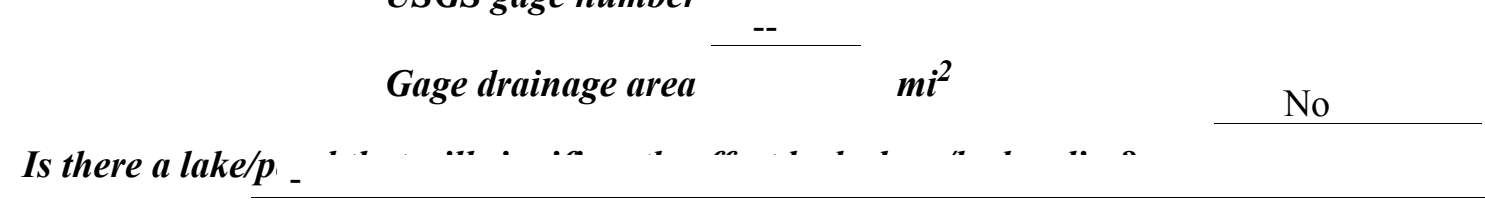

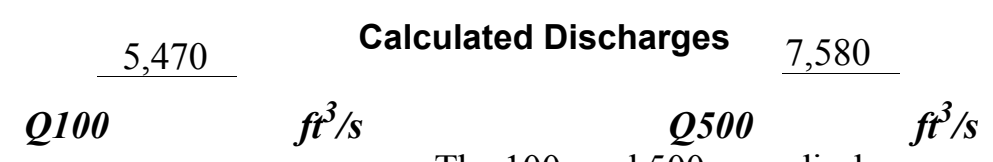

The 100- and 500-year discharges are based on a

drainage area relationship [(37.9/42.0)exp 0.67] with the drainage area above the confluence of Mill Brook with the Connecticut River. This drainage area is 42.0 square miles and has flood frequency estimates available from the Flood Insurance Study for the town of Windsor (Federal Emergency Management Agency, 1988). The values used were within a range defined by flood frequency curves developed from several empirical methods (Benson, 1962; Johnson and Tasker, 1974; FHWA, 1983; Potter, 1957a\&b; Talbot, 1887). 


\section{Description of the Water-Surface Profile Model (WSPRO) Analysis}

Datum for WSPRO analysis (USGS survey, sea level, VTAOT plans)

USGS survey

Datum tie between USGS survey and VTAOT plans

None

Description of reference marks used to determine USGS datum. $\quad$ RM1 is a chiseled X on top of the upstream end of the right abutment (elev. $499.75 \mathrm{ft}$, arbitrary survey datum). RM2 is the painted corner on the downstream left end of the bridge curb (elev. $500.62 \mathrm{ft}$, arbitrary survey datum). RM3 is a chiseled $\mathrm{X}$ on top of the upstream left wingwall, $1.5 \mathrm{ft}$ from the end of the left abutment (elev. $499.73 \mathrm{ft}$, arbitrary survey datum).

\section{Cross-Sections Used in WSPRO Analysis}

\begin{tabular}{cccl}
\hline${ }^{1}$ Cross-section & $\begin{array}{c}\text { Section } \\
\text { Reference } \\
\text { Distance } \\
\text { (SRD) } \text { in feet }\end{array}$ & $\begin{array}{c}{ }^{2} \text { Cross-section } \\
\text { development }\end{array}$ & \multicolumn{1}{c}{ Comments } \\
\hline EXITX & -54 & 1 & $\begin{array}{l}\text { Exit section } \\
\text { Downstream Full-valley } \\
\text { section (Templated from } \\
\text { EXITX) }\end{array}$ \\
BRIDG & 0 & 2 & $\begin{array}{l}\text { Bridge section } \\
\text { Road Grade section }\end{array}$ \\
RDWAY & 0 & 1 & $\begin{array}{l}\text { Modelled Approach sec- } \\
\text { tion (Templated from } \\
\text { APPRO }\end{array}$ \\
& 11 & 1 & $\begin{array}{l}\text { APTEM) } \\
\text { Approach section as sur- } \\
\text { veyed (Used as a tem- } \\
\text { plate) }\end{array}$ \\
\hline
\end{tabular}

${ }^{1}$ For location of cross-sections see plan-view sketch included with Level I field form, Appendix E. For more detail on how cross-sections were developed see WSPRO input file. 


\section{Data and Assumptions Used in WSPRO Model}

Hydraulic analyses of the reach were done by use of the Federal Highway Administration's WSPRO step-backwater computer program (Shearman and others, 1986, and Shearman, 1990). The analyses reported herein reflect conditions existing at the site at the time of the study. Furthermore, in the development of the model it was necessary to assume no accumulation of debris or ice at the site. Results of the hydraulic model are presented in the Bridge Hydraulic Summary, appendix B, and figure 7.

Channel roughness factors (Manning's " $n$ ") used in the hydraulic model were estimated using field inspections at each cross section following the general guidelines described by Arcement and Schneider (1989). Final adjustments to the values were made during the modelling of the reach. Channel " $n$ " values for the reach ranged from 0.035 to 0.060 , and overbank " $n$ " values ranged from 0.070 to 0.080 .

Normal depth at the exit section (EXITX) was assumed as the starting water surface. This depth was computed by use of the slope-conveyance method outlined in the user's manual for WSPRO (Shearman, 1990). The slope used was $0.0102 \mathrm{ft} / \mathrm{ft}$, which was estimated from surveyed thalweg points.

The surveyed approach section (APTEM) was moved along the approach channel slope $(0.0080 \mathrm{ft} / \mathrm{ft})$ to establish the modelled approach section (APPRO), one bridge length upstream of the upstream face as recommended by Shearman and others (1986). This location provides a consistent method for determining scour variables.

For the 100-year and 500-year discharges, WSPRO assumes critical depth at the bridge section. Supercritical models were developed for these discharges. After analyzing both the supercritical and subcritical profiles for each discharge, it was determined that the water surface

profile does pass through critical depth within the bridge opening. Thus, the assumptions of critical depth at the bridge are satisfactory solutions. 


\section{Bridge Hydraulics Summary}

$\begin{array}{llll}\text { Average bridge embankment elevation } & 500.5 & f t \\ \text { Average low steel elevation } & 496.8 & \boldsymbol{f t}\end{array}$

100-year discharge $\quad 5,470 \quad \mathrm{ft}^{3} / \mathrm{s}$

Water-surface elevation in bridge opening $\quad 490.6 \quad f t$

Road overtopping? ___ No Discharge over road ___ - $\mathrm{ft}^{3} / \mathrm{s}$

Area of flow in bridge opening $\quad 354 \quad \mathrm{ft}^{2}$

Average velocity in bridge opening $15.5 \quad \mathrm{ft} / \mathrm{s}$

Maximum WSPRO tube velocity at bridge $\quad 19.0 \mathrm{ft} / \mathrm{s}$

Water-surface elevation at Approach section with bridge 493.6

Water-surface elevation at Approach section without bridge $\quad 492.3$

Amount of backwater caused by bridge

$1.3 \quad$ it

500-year discharge $\quad 7,580 \quad \mathrm{ft}^{3} / \mathrm{s}$

Water-surface elevation in bridge opening

$492.4 \mathrm{ft}$

Road overtopping? ___ No Discharge over road ___ _ $\quad f t^{3} / s$

Area of flow in bridge opening $\quad 441 \quad \mathrm{ft}^{2}$

Average velocity in bridge opening $\quad 17.2 \mathrm{ft} / \mathrm{s}$

Maximum WSPRO tube velocity at bridge 21.5 , s

Water-surface elevation at Approach section with bridge 496.1

Water-surface elevation at Approach section without bridge $\quad 494.1$

Amount of backwater caused by bridge $\quad 2.0$, $t$

Incipient overtopping discharge ___ _ $\mathrm{ft}^{3} / \mathrm{s}$

Water-surface elevation in bridge opening $\quad-\quad t$

Area of flow in bridge opening $f t^{2}$

Average velocity in bridge opening

Maximum WSPRO tube velocity at bridge

$-\quad f t^{2}$

$f t / s$

Water-surface elevation at Approach section with bridge

Water-surface elevation at Approach section without bridge

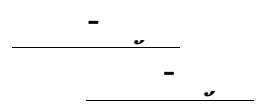

Amount of backwater caused by bridge

$-\quad$ it 


\section{Scour Analysis Summary}

\section{Special Conditions or Assumptions Made in Scour Analysis}

Scour depths were computed using the general guidelines described in Hydraulic Engineering Circular 18 (Richardson and Davis, 1995). Scour depths were calculated assuming an infinite depth of erosive material and a homogeneous particle-size distribution. The results of the scour analyses for the 100- and 500-year discharges are presented in tables 1 and 2 and the scour depths are shown graphically in figure 8 .

Contraction scour for the 100-year and 500-year discharges was computed by use of the Laursen live-bed contraction scour equation (Richardson and Davis, 1995, p. 30, equation 17). Variables for the Laursen clear-water contraction scour equation include the discharge through the bridge, the width of the channel at the bridge, and the median grain size of the channel bed material.

Abutment scour was computed by use of the Froehlich equation (Richardson and Davis, 1995, p. 48, equation 28). Variables for the Froehlich equation include the Froude number of the flow approaching the embankments, the length of the embankment blocking flow, and the depth of flow approaching the embankment less any roadway overtopping. 


\section{Scour Results}

100-yr discharge 500-yr discharge

Incipient

Contraction scour:

(Scour depths in feet)

Main channel

Live-bed scour
Clear-water scour
Depth to armoring
bank
erbank

Right overbank

Local scour:

Abutment scour

Left abutment

11.0

12.8

12.5

14.3-

\section{Right abutment}

Pier scour

Pier 1

Pier 2

Pier 3

Abutments:

Left abutment

Right abutment

Piers:

Pier 1

Pier 2

overtopping discharge

Left overbank

(Scour depths infeet)
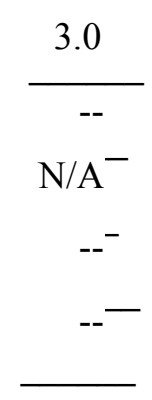
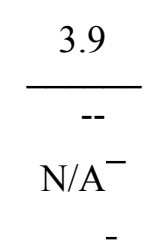

$-$

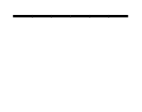

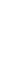


$\vec{u}$

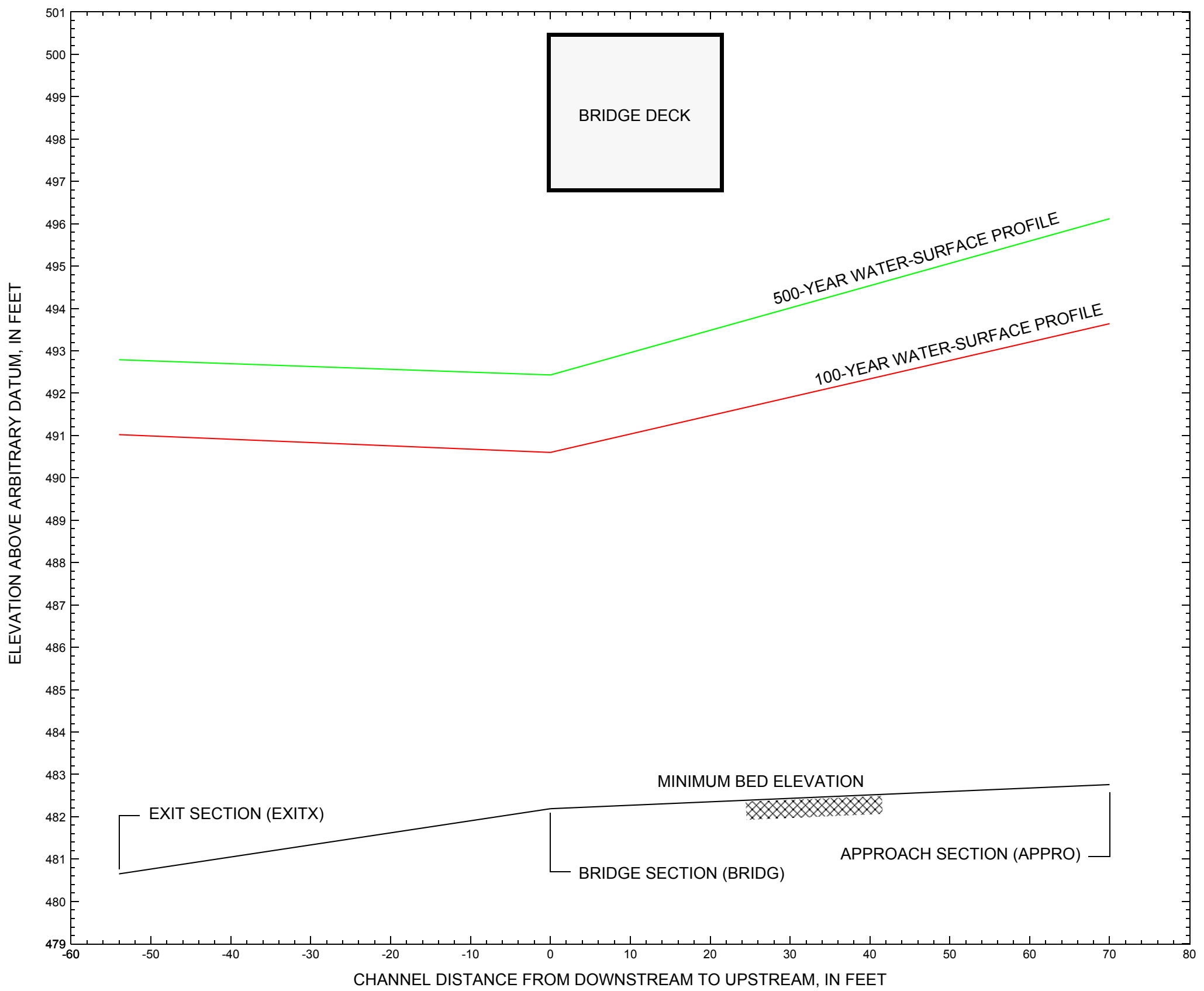

Figure 7. Water-surface profiles for the 100- and 500-year discharges at structure WNDSTH00070023 on Town Highway 7, crossing Mill Brook, Windsor, Vermont. 


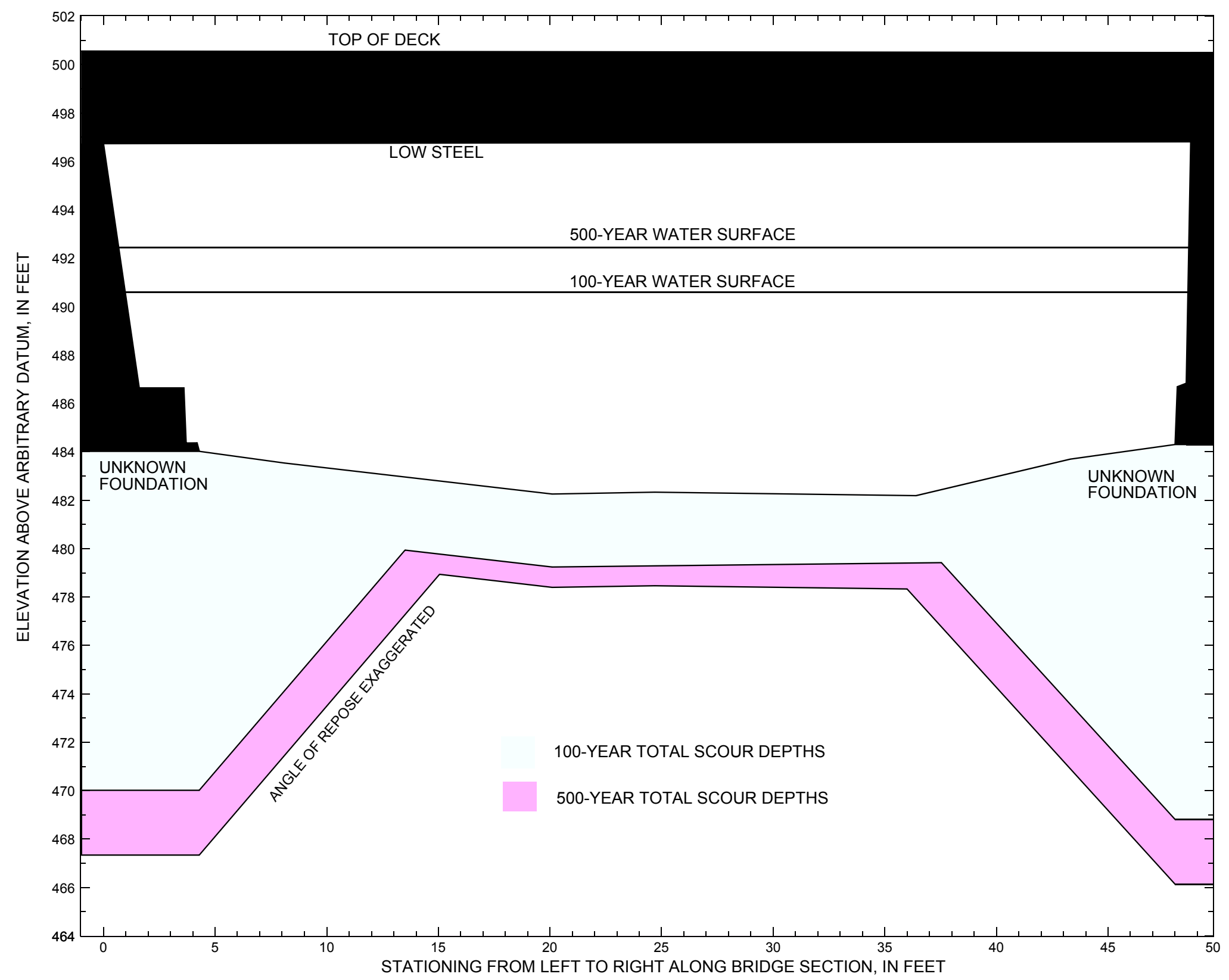

Figure 8. Scour elevations for the 100- and 500-year discharges at structure WNDSTH00070023 on Town Highway 7, crossing Mill Brook, Windsor, Vermont. 


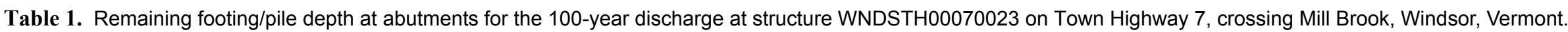
[VTAOT, Vermont Agency of Transportation; --, no data]

\begin{tabular}{|c|c|c|c|c|c|c|c|c|c|c|c|}
\hline Description & Station ${ }^{1}$ & $\begin{array}{l}\text { VTAOT } \\
\text { minimum } \\
\text { low-chord } \\
\text { elevation } \\
\text { (feet) }\end{array}$ & $\begin{array}{c}\text { Surveyed } \\
\text { minimum } \\
\text { low-chord } \\
\text { elevation } \\
\text { (feet) }\end{array}$ & $\begin{array}{c}\text { Bottom of } \\
\text { footing/pile } \\
\text { elevation }{ }^{2} \\
\text { (feet) }\end{array}$ & $\begin{array}{c}\text { Channel } \\
\text { elevation at } \\
\text { abutment/ } \\
\text { pier }^{2} \\
\text { (feet) }\end{array}$ & $\begin{array}{l}\text { Contraction } \\
\text { scour depth } \\
\text { (feet) }\end{array}$ & $\begin{array}{l}\text { Abutment } \\
\text { scour } \\
\text { depth } \\
\text { (feet) }\end{array}$ & $\begin{array}{l}\text { Pier } \\
\text { scour } \\
\text { depth } \\
\text { (feet) }\end{array}$ & $\begin{array}{l}\text { Depth of } \\
\text { total scour } \\
\text { (feet) }\end{array}$ & $\begin{array}{c}\text { Elevation of } \\
\text { scour }^{2} \\
\text { (feet) }\end{array}$ & $\begin{array}{c}\text { Remaining } \\
\text { footing/pile } \\
\text { depth } \\
\text { (feet) }\end{array}$ \\
\hline \multicolumn{12}{|c|}{100 -year discharge is 5,470 cubic-feet per second } \\
\hline Left abutment & 0.0 & -- & 496.7 & -- & 484.0 & 3.0 & 11.0 & -- & 14.0 & 470.0 & -- \\
\hline Right abutment & 48.7 & -- & 496.8 & -- & 484.3 & 3.0 & 12.5 & -- & 15.5 & 468.8 & -- \\
\hline
\end{tabular}

1.Measured along the face of the most constricting side of the bridge.

2.Arbitrary datum for this study.

Table 2. Remaining footing/pile depth at abutments for the 500-year discharge at structure WNDSTH00070023 on Town Highway 7, crossing Mill Brook, Windsor, Vermont. [VTAOT, Vermont Agency of Transportation; --, no data]

\begin{tabular}{|c|c|c|c|c|c|c|c|c|c|c|c|}
\hline Description & Station $^{1}$ & $\begin{array}{l}\text { VTAOT } \\
\text { minimum } \\
\text { low-chord } \\
\text { elevation } \\
\text { (feet) }\end{array}$ & $\begin{array}{l}\text { Surveyed } \\
\text { minimum } \\
\text { low-chord } \\
\text { elevation } \\
\text { (feet) }\end{array}$ & $\begin{array}{c}\text { Bottom of } \\
\text { footing/pile } \\
\text { elevation }{ }^{2} \\
\text { (feet) }\end{array}$ & $\begin{array}{c}\text { Channel } \\
\text { elevation at } \\
\text { abutment/ } \\
\text { pier }^{2} \\
\text { (feet) }\end{array}$ & $\begin{array}{c}\text { Contraction } \\
\text { scour depth } \\
\text { (feet) }\end{array}$ & $\begin{array}{l}\text { Abutment } \\
\text { scour } \\
\text { depth } \\
\text { (feet) }\end{array}$ & $\begin{array}{l}\text { Pier } \\
\text { scour } \\
\text { depth } \\
\text { (feet) }\end{array}$ & $\begin{array}{l}\text { Depth of } \\
\text { total scour } \\
\text { (feet) }\end{array}$ & $\begin{array}{c}\text { Elevation of } \\
\text { scour }^{2} \\
\text { (feet) }\end{array}$ & $\begin{array}{c}\text { Remaining } \\
\text { footing/pile } \\
\text { depth } \\
\text { (feet) }\end{array}$ \\
\hline \multicolumn{12}{|c|}{500 -year discharge is 7,580 cubic-feet per second } \\
\hline Left abutment & 0.0 & -- & 496.7 & -- & 484.0 & 3.9 & 12.8 & -- & 16.7 & 467.3 & -- \\
\hline Right abutment & 48.7 & -- & 496.8 & -- & 484.3 & 3.9 & 14.3 & -- & 18.2 & 466.1 & -- \\
\hline
\end{tabular}

1.Measured along the face of the most constricting side of the bridge.

2.Arbitrary datum for this study. 


\section{SELECTED REFERENCES}

Arcement, G.J., Jr., and Schneider, V.R., 1989, Guide for selecting Manning's roughness coefficients for natural channels and flood plains: U.S. Geological Survey Water-Supply Paper 2339, 38 p.

Barnes, H.H., Jr., 1967, Roughness characteristics of natural channels: U.S. Geological Survey Water-Supply Paper 1849,213 p.

Benson, M. A., 1962, Factors Influencing the Occurrence of Floods in a Humid Region of Diverse Terrain: U.S. Geological Survey WaterSupply Paper 1580-B, 64 p.

Brown, S.A. and Clyde, E.S., 1989, Design of riprap revetment: Federal Highway Administration Hydraulic Engineering Circular No. 11, Publication FHWA-IP-89-016, 156 p.

Federal Emergency Management Agency, 1988, Flood Insurance Study, Town of Windsor, Windsor County, Vermont: Washington, D.C., June 15, 1988.

Federal Highway Administration, 1983, Runoff estimates for small watersheds and development of sound design: Federal Highway Administration Report FHWA-RD-77-158.

Federal Highway Administration, 1993, Stream Stability and Scour at Highway Bridges: Participant Workbook: Federal Highway Administration Report FHWA-HI-91-011.

Froehlich, D.C., 1989, Local scour at bridge abutments in Ports, M.A., ed., Hydraulic Engineering--Proceedings of the 1989 National Conference on Hydraulic Engineering: New York, American Society of Civil Engineers, p. 13-18.

Hayes, D.C.,1993, Site selection and collection of bridge-scour data in Delaware, Maryland, and Virginia: U.S. Geological Survey WaterResources Investigation Report 93-4017, 23 p.

Interagency Advisory Committee on Water Data, 1982, Guidelines for determining flood flow frequency: U.S. Geological Survey, Bulletin 17B of the Hydrology Subcommittee, 190 p.

Johnson, C.G. and Tasker, G.D.,1974, Progress report on flood magnitude and frequency of Vermont streams: U.S. Geological Survey OpenFile Report 74-130, 37 p.

Lagasse, P.F., Schall, J.D., Johnson, F., Richardson, E.V., Chang, F., 1995, Stream Stability at Highway Structures: Federal Highway Administration Hydraulic Engineering Circular No. 20, Publication FHWA-IP-90-014, 144 p.

Laursen, E.M., 1960, Scour at bridge crossings: Journal of the Hydraulics Division, American Society of Civil Engineers, v. 86, no. HY2, p. 39-53.

Potter, W. D., 1957a, Peak rates of runoff in the Adirondack, White Mountains, and Maine woods area, Bureau of Public Roads

Potter, W. D., 1957b, Peak rates of runoff in the New England Hill and Lowland area, Bureau of Public Roads

Richardson, E.V. and Davis, S.R., 1995, Evaluating scour at bridges: Federal Highway Administration Hydraulic Engineering Circular No. 18, Publication FHWA-IP-90-017, 204 p.

Richardson, E.V., Simons, D.B., and Julien, P.Y., 1990, Highways in the river environment: Federal Highway Administration Publication FHWA-HI-90-016.

Ritter, D.F., 1984, Process Geomorphology: W.C. Brown Co., Debuque, Iowa, 603 p.

Shearman, J.O., 1990, User's manual for WSPRO--a computer model for water surface profile computations: Federal Highway Administration Publication FHWA-IP-89-027, 187 p.

Shearman, J.O., Kirby, W.H., Schneider, V.R., and Flippo, H.N., 1986, Bridge waterways analysis model; research report: Federal Highway Administration Publication FHWA-RD-86-108, 112 p.

Talbot, A.N., 1887, The determination of water-way for bridges and culverts.

U.S. Geological Survey, 1984, Mt. Ascutney, Vermont 7.5 x 15 Minute Series quadrangle map: U.S. Geological Survey Topographic Maps, Scale 1:25,000. 


\section{APPENDIX A: \\ WSPRO INPUT FILE}




\section{WSPRO INPUT FILE}

GR

GR

GR

GR

GR

*

$\mathrm{N}$

SA

*

XS

*

*

BR

GR

GR

GR

GR

GR

*

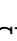

CD

$\mathrm{N}$

*

*

$\mathrm{XR}$

GR

GR

GR

GR

*

$\mathrm{XT}$

GR

GR

GR

GR

GR

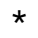

*

AS

GT

$\mathrm{N}$

SA

*

HP 1 BRIDG

HP 2 BRIDG

HP 1 APPRO

HP 2 APPRO
U.S. Geological Survey WSPRO Input File wnds023.wsp Hydraulic analysis for structure WNDSTH00070023 Date: 02-JAN-98 TH 7 CROSSING MILL BROOK IN WINDSOR, VT

RLB

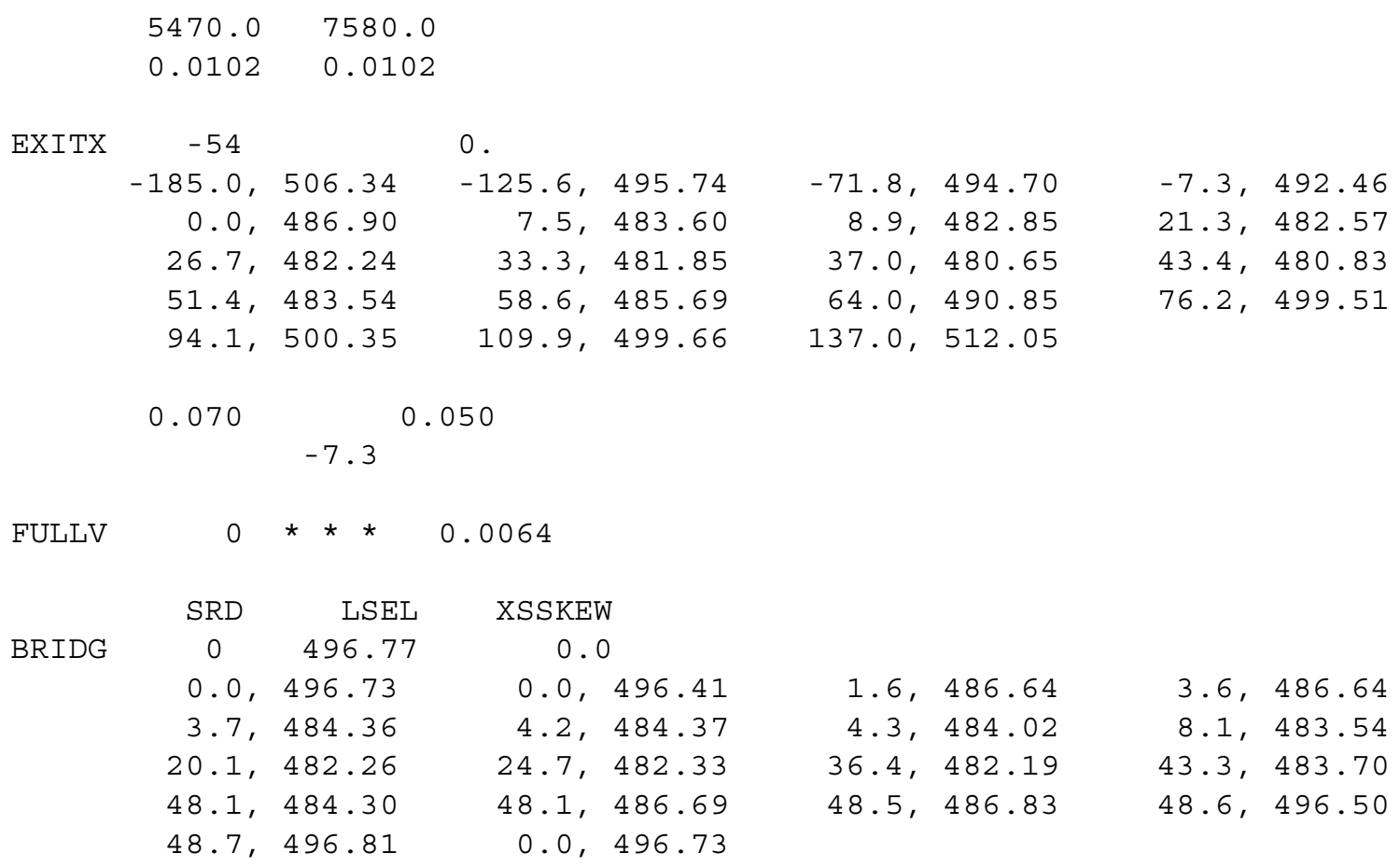




\section{APPENDIX B: \\ WSPRO OUTPUT FILE}


WSPRO OUTPUT FILE

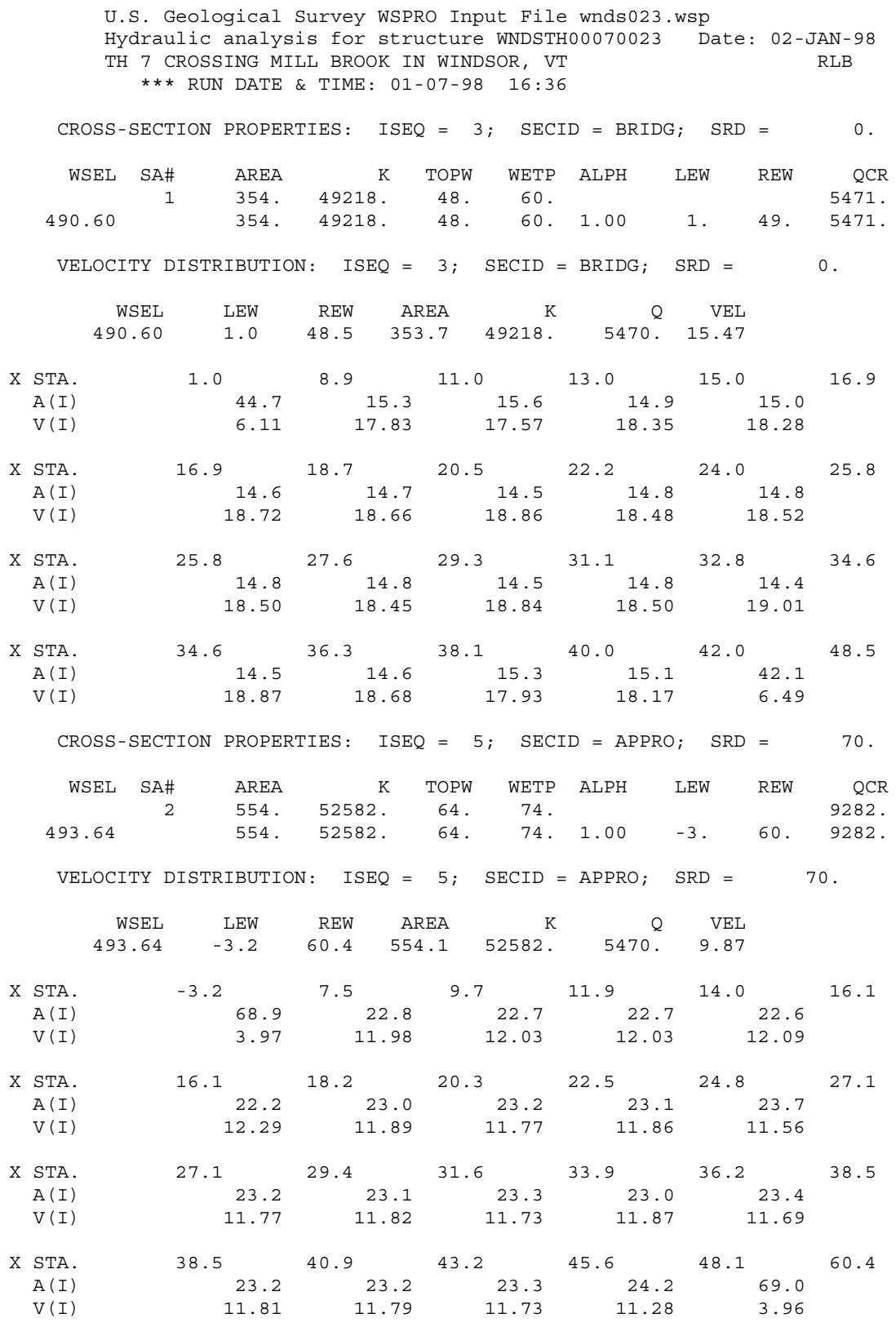


WSPRO OUTPUT FILE (continued)

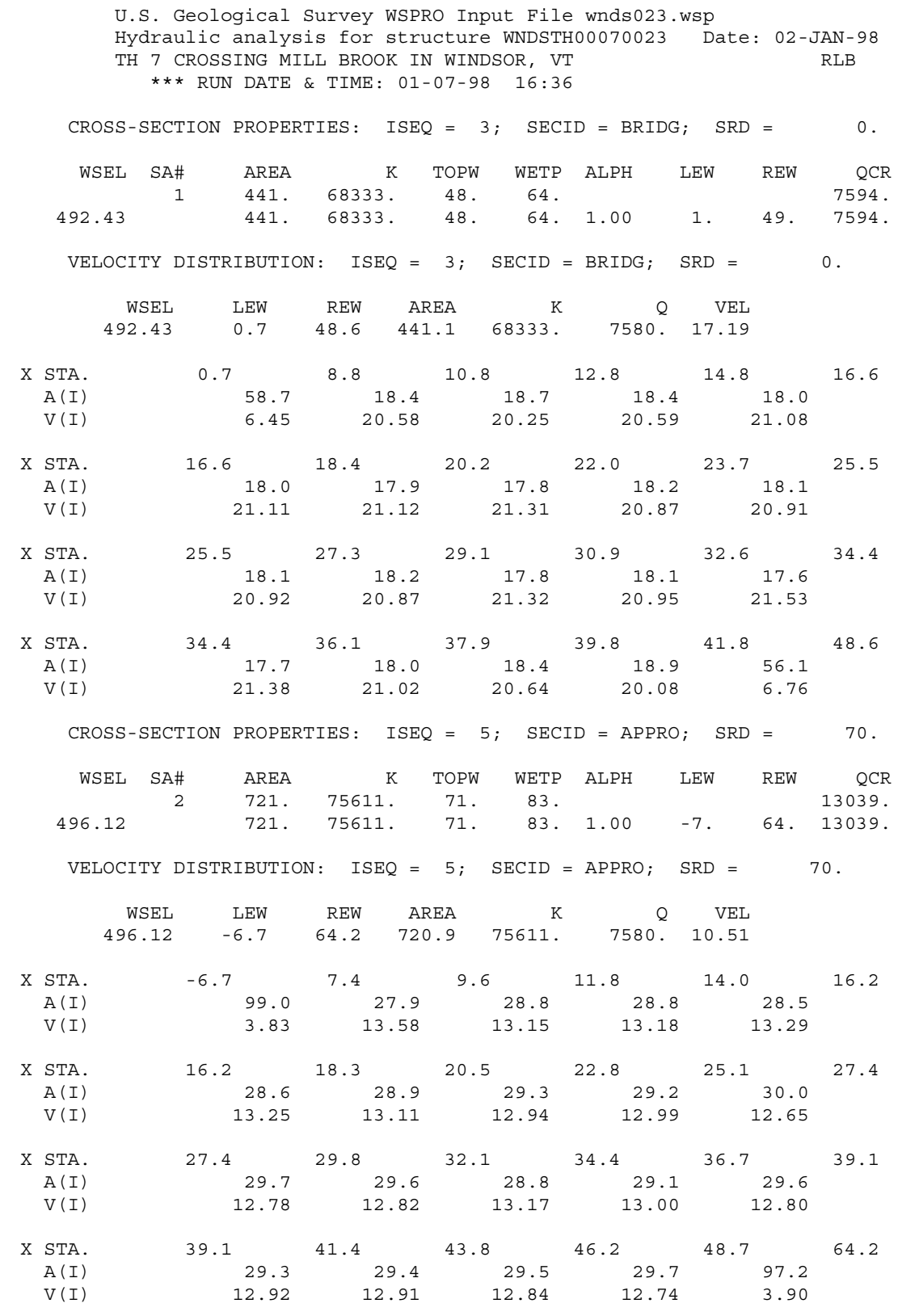


WSPRO OUTPUT FILE (continued)

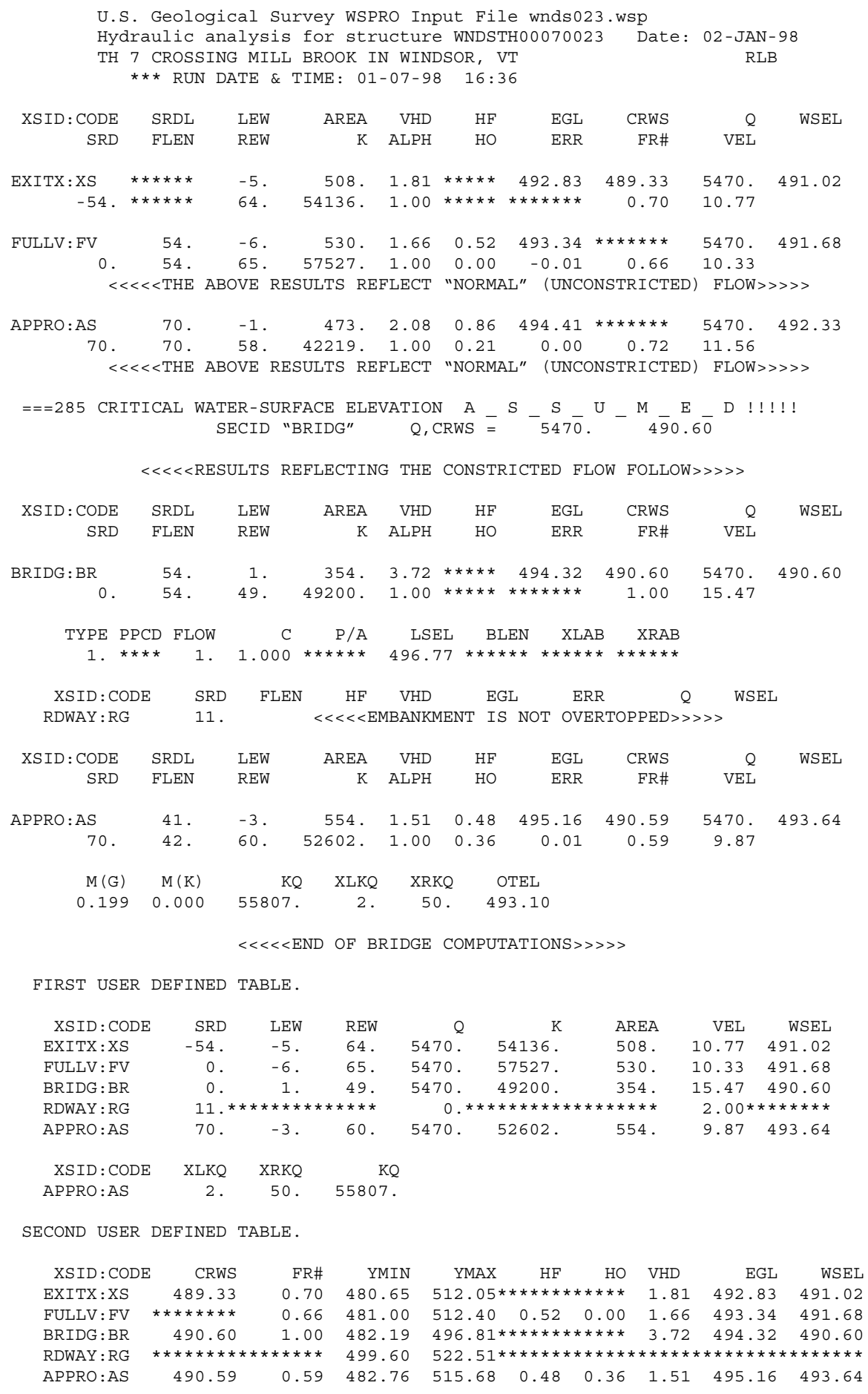


WSPRO OUTPUT FILE (continued)

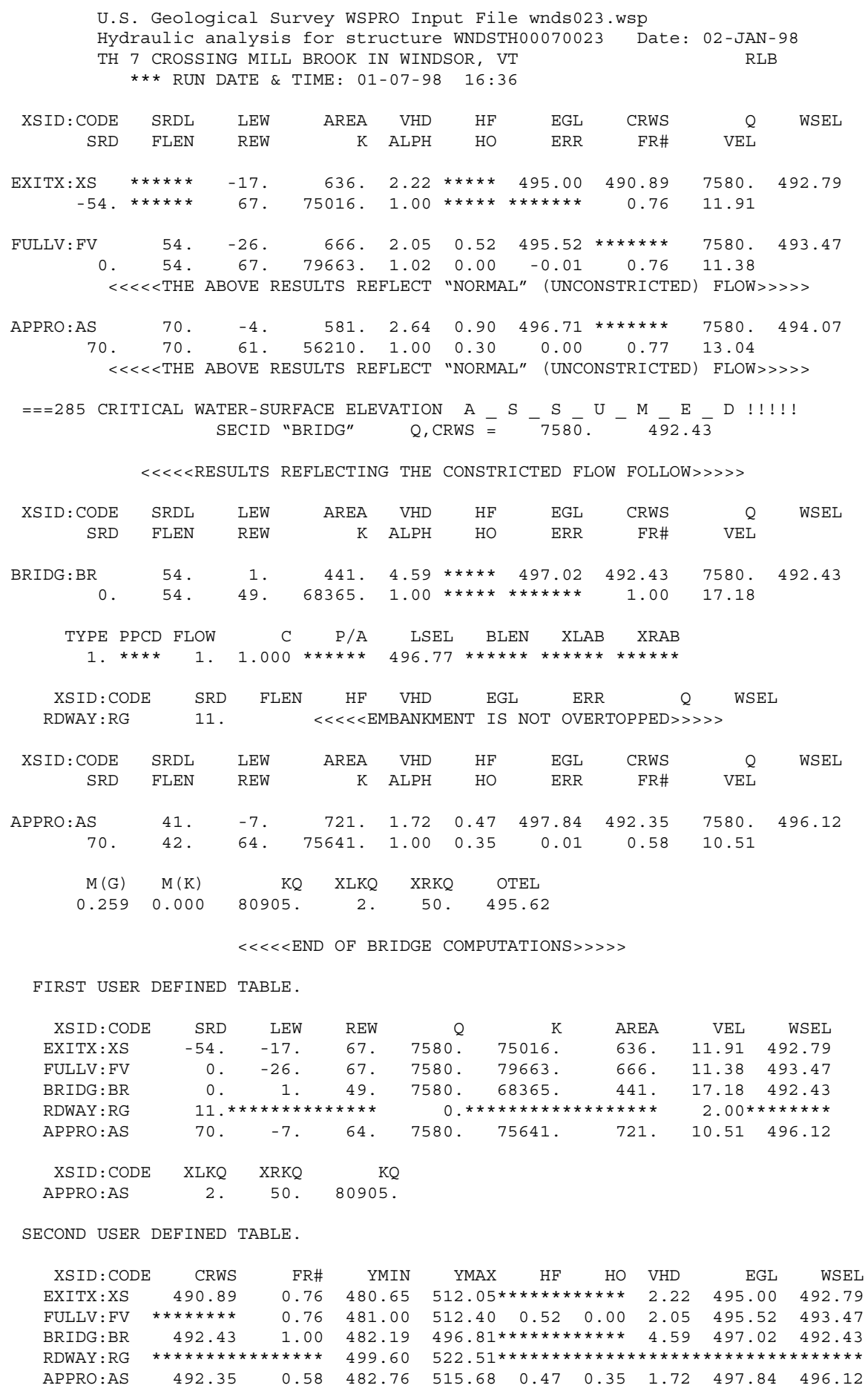




\section{APPENDIX C:}

\section{BED-MATERIAL PARTICLE-SIZE DISTRIBUTION}




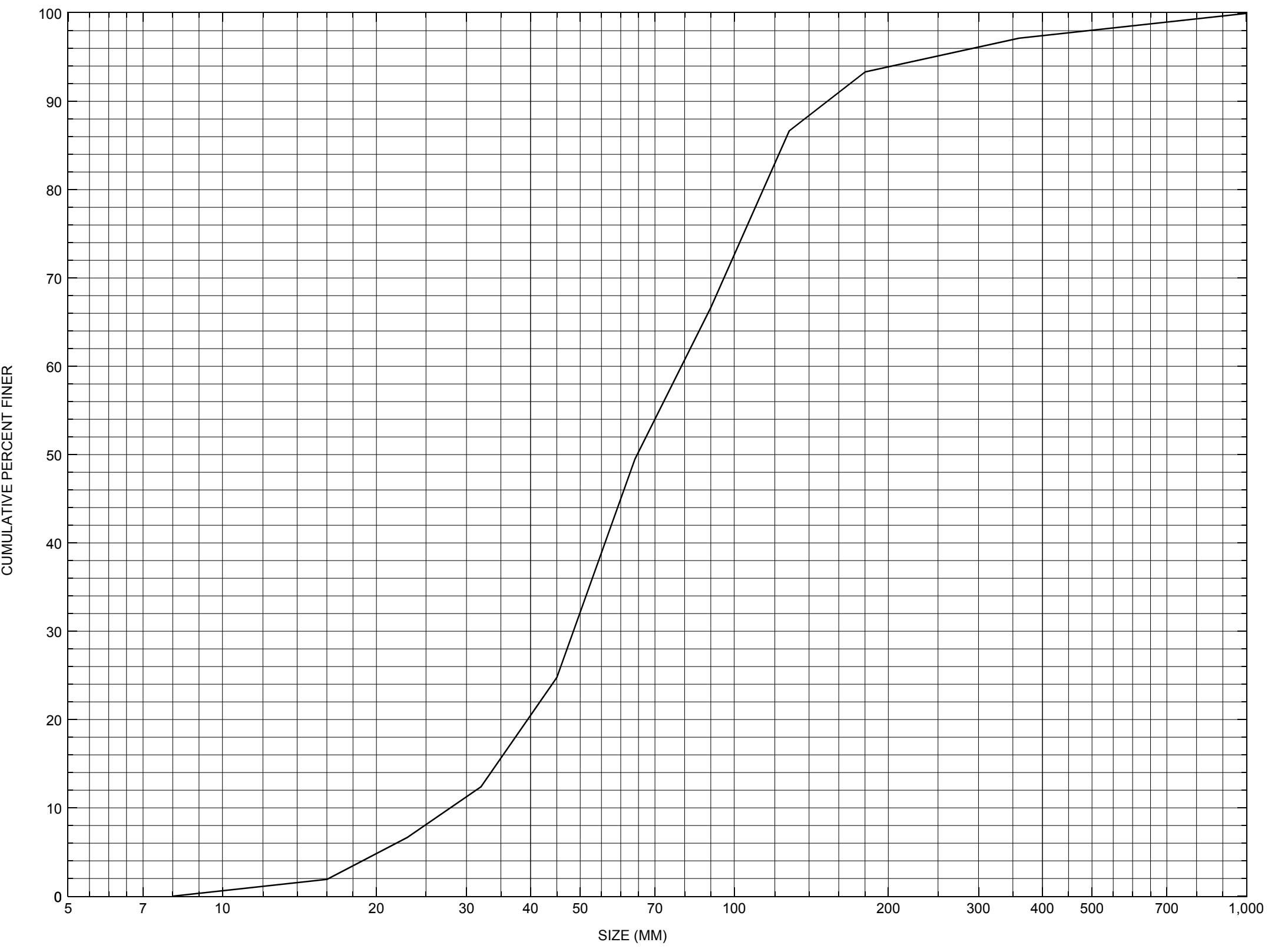

Appendix C. Bed material particle-size distribution for a pebble count in the channel approach of structure WNDSTH00070023, in Windsor, Vermont. 


\section{APPENDIX D: \\ HISTORICAL DATA FORM}




\section{Structure Number WNDSTH00070023}

\section{General Location Descriptive}

Data collected by (First Initial, Full last name) $\underline{\mathbf{E}}$. BOEHMLER

Date $(M M / D D / Y Y) \_\mathbf{0 3} / \underline{23} / \underline{95}$

Highway District Number (I - 2; nn) $\mathbf{0 4}$

Town (FIPS place code; I - 4; nnnnn) $\mathbf{8 4 9 2 5}$

Waterway (I - 6) MILL BROOK

Route Number $\underline{\text { TH007 }}$

Topographic Map Mt. Ascutney

Latitude (I - 16; nnnn.n) $\mathbf{4 3 2 8 1}$
County (FIPS county code; I - 3; nnn)

Mile marker (I - 11; nnn.nnn) $\mathbf{0 0 0 0 0 0}$

Road Name (I - 7): -

Vicinity (I - 9)@ JCT W CL3 TH6

Hydrologic Unit Code: $\mathbf{0 1 0 8 0 1 0 4}$

Longitude (i - 17; nnnnn.n) $\mathbf{7 2 2 5 7}$

\section{Select Federal Inventory Codes}

FHWA Structure Number (I - 8) $\mathbf{1 0 1 4 2 3 0 0 2 3 1 4 2 3}$

Maintenance responsibility $(I-21 ; n n) \quad \mathbf{0 3}$

Year built (I - 27; YYYY) 1947

Average daily traffic, ADT (I - 29; nnnnnn) 000150

Year of ADT (I - 30; YY) $\mathbf{9 1}$

Opening skew to Roadway $(I-34 ; n n) \quad \mathbf{0 0}$

Operational status $(I-41 ; X) \quad \mathbf{A}$

Structure type (I - 43; nnn) $\mathbf{3 0 2}$

Approach span structure type $(I-44 ; n n n)$ 000

Number of spans (I - 45; nnn) $\mathbf{0 0 1}$

Number of approach spans (I - 46; nnnn) $\mathbf{0 0 0 0}$

Comments:

The structural inspection report of 9/11/93 indicates the structure is a single span, steel stringer bridge with a concrete deck and an asphalt roadway surface. The abutments are concrete. The right abutment concrete is noted as clean. The left abutment concrete is reported as having a fairly large area of delamination concrete. A crack also may be seen in the bridge seat above. Along the bottom of the left abutment the report mentions a large concrete subfooting, which has been slightly undermined at its upstream end. The footing on the right abutment is exposed as well, with some minor spalling at the end. The report mentions that bank erosion and debris accumulation near this site are not evident. (Continued, page 31) 


\section{Bridge Hydrologic Data}

Is there hydrologic data available? $\underline{\mathbf{N}}$ if No, type ctrl-n $h \quad$ VTAOT Drainage area $\left(m i^{2}\right)$ : -

Terrain character:

Stream character \& type: -

Streambed material:

Discharge Data (cfs):

$$
\begin{aligned}
& Q_{2.33}- \\
& Q_{50}-
\end{aligned}
$$

Record flood date $(M M / D D / Y Y)$ :

Estimated Discharge (cfs): Ice conditions (Heavy, Moderate, Light) : -

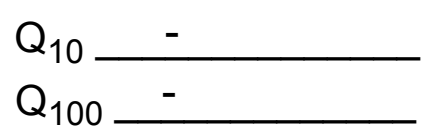

$$
\begin{aligned}
& Q_{25}- \\
& Q_{500}-
\end{aligned}
$$

Water surface elevation $(f t):-$

The stage increases to maximum highwater elevation (Rapidly, Not rapidly):

The stream response is (Flashy, Not flashy):

Describe any significant site conditions upstream or downstream that may influence the stream's stage: -

Watershed storage area (in percent): _ _ \%

The watershed storage area is: - (1-mainly at the headwaters; 2- uniformly distributed; 3-immediatly upstream oi the site)

Water Surface Elevation Estimates for Existing Structure:

\begin{tabular}{|l|l|l|l|l|l|}
\hline Peak discharge frequency & $Q_{2.33}$ & $Q_{10}$ & $Q_{25}$ & $Q_{50}$ & $Q_{100}$ \\
Water surface elevation (ft)) & - & - & - & - & - \\
Velocity (ft/sec) & - & - & - & - & - \\
\hline
\end{tabular}

Long term stream bed changes: -

Is the roadway overtopped below the $\mathrm{Q}_{100}$ ? (Yes, No, Unknown): $\mathbf{U}$ Frequency: Relief Elevation (ft): Discharge over roadway at $Q_{100}\left(f^{3} / \mathrm{sec}\right)$ :

Are there other structures nearby? (Yes, No, Unknown): $\underline{\mathbf{U}}$ Upstream distance (miles): Town: If No or Unknown, type ctrl-n os Highway No. : Structure No. : Year Built:

Clear span (ft): Clear Height $(f t)$ : Full Waterway $\left(f^{2}\right)$ : 
Downstream distance (miles): Town: Year Built:

Highway No. : Structure No. : Structure Type:

Clear span (ft): Clear Height $(f t)$ : Full Waterway $\left(f^{2}\right)$ :

Comments:

The waterway proceeds straight through the crossing. The streambed material consists of mainly stone and gravel. Some stone fill at the upstream end of the left abutment is recommended in the report.

\section{USGS Watershed Data}

Watershed Hydrographic Data

Drainage area $(D A) \underline{37.86} \mathrm{mi}^{2}$ Lake/pond/swamp area 0.03 $\mathrm{mi}^{2}$

Watershed storage (ST) 0.08

Bridge site elevation 591

Main channel length 14.27 Headwater elevation 3093 $\mathrm{ft}$ $10 \%$ channel length elevation $\mathbf{6 8 9}$ $\mathrm{ft} \quad 85 \%$ channel length elevation $\mathrm{ft}$

Main channel slope (S) (S) $\mathrm{ft} / \mathrm{mi}$

Watershed Precipitation Data

Average site precipitation in Average headwater precipitation in

Maximum 2yr-24hr precipitation event $(I 24,2)$ in

Average seasonal snowfall (Sn) $\mathrm{ft}$ 


\section{Bridge Plan Data}

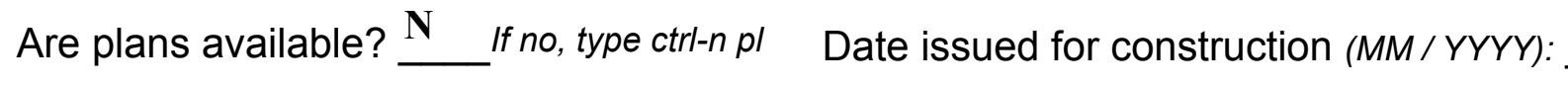

Project Number

Minimum channel bed elevation:

Low superstructure elevation: USLAB DSLAB USRAB DSRAB Benchmark location description:

NO BENCHMARK INFORMATION

Reference Point (MSL, Arbitrary, Other): Datum (NAD27, NAD83, Other):

Foundation Type: 4

If 1 : Footing Thickness

If 2: Pile Type:

If 3: Footing bottom elevation:

Is boring information available? $\mathbf{N}$

Foundation Material Type: $\mathbf{3}$

(1-Spreadfooting; 2-Pile; 3- Gravity; 4-Unknown)

Footing bottom elevation: -

Briefly describe material at foundation bottom elevation or around piles:

NO FOUNDATION MATERIAL INFORMATION 


\section{Cross-sectional Data}

Is cross-sectional data available? $\mathbf{N}$ If no, type ctrl-n xs

Source (FEMA, VTAOT, Other)? -

Comments: NO CROSS SECTION INFORMATION

\begin{tabular}{|l|l|l|l|l|l|l|l|l|l|l|l|}
\hline Station & - & - & - & - & - & - & - & - & - & - & - \\
\hline Feature & - & - & - & - & - & - & - & - & - & - & - \\
\hline $\begin{array}{l}\text { Low chord } \\
\text { elevation }\end{array}$ & - & - & - & - & - & - & - & - & - & - & - \\
\hline $\begin{array}{l}\text { Bed } \\
\text { elevation }\end{array}$ & - & - & - & - & - & - & - & - & - & - & - \\
\hline $\begin{array}{l}\text { Low chord } \\
\text { to bed }\end{array}$ & - & - & - & - & - & - & - & - & - & - & - \\
\hline Station & - & - & - & - & - & - & - & - & - & - & - \\
\hline Feature & - & - & - & - & - & - & - & - & - & - & - \\
\hline $\begin{array}{l}\text { Low chord } \\
\text { elevation }\end{array}$ & - & - & - & - & - & - & - & - & - & - & - \\
\hline $\begin{array}{l}\text { Bed } \\
\text { elevation }\end{array}$ & - & - & - & - & - & - & - & - & - & - & - \\
\hline $\begin{array}{l}\text { Low chord } \\
\text { to bed }\end{array}$ & - & - & - & - & - & - & - & - & - & - & - \\
\hline
\end{tabular}

Source (FEMA, VTAOT, Other)?

Comments: NO CROSS SECTION INFORMATION

\begin{tabular}{|l|l|l|l|l|l|l|l|l|l|l|l|}
\hline Station & - & - & - & - & - & - & - & - & - & - & - \\
\hline Feature & - & - & - & - & - & - & - & - & - & - & - \\
\hline $\begin{array}{l}\text { Low chord } \\
\text { elevation }\end{array}$ & - & - & - & - & - & - & - & - & - & - & - \\
\hline $\begin{array}{l}\text { Bed } \\
\text { elevation }\end{array}$ & - & - & - & - & - & - & - & - & - & - & - \\
\hline $\begin{array}{l}\text { Low chord } \\
\text { to bed }\end{array}$ & - & - & - & - & - & - & - & - & - & - & - \\
\hline Station & - & - & - & - & - & - & - & - & - & - & - \\
\hline Feature & - & - & - & - & - & - & - & - & - & - & - \\
\hline $\begin{array}{l}\text { Low chord } \\
\text { elevation }\end{array}$ & - & - & - & - & - & - & - & - & - & - & - \\
\hline $\begin{array}{l}\text { Bed } \\
\text { elevation }\end{array}$ & - & - & - & - & - & - & - & - & - & - & - \\
\hline $\begin{array}{l}\text { Low chord } \\
\text { to bed }\end{array}$ & - & - & - & - & - & - & - & - & - & - & - \\
\hline
\end{tabular}




\section{APPENDIX E: \\ LEVEL I DATA FORM}


U. S. Geological Survey

Bridge Field Data Collection and Processing Form

Qa/Qc Check by: EW Date: $\underline{\mathbf{1 0} / \mathbf{1 7} / 96}$

\section{A. General Location Descriptive}

1. Data collected by (First Initial, Full last name) $\mathbf{R}$. BURNS

2. Highway District Number 04

County WINDSOR (027)

Waterway (I - 6) MILL BROOK

Route Number $\mathbf{\text { TH007 }}$

3. Descriptive comments:

This bridge is located at the junction with CL3 TH6.
Mile marker 000000

Town WINDSOR (84925)

Road Name -

Hydrologic Unit Code: $\mathbf{0 1 0 8 0 1 0 4}$

Date $(M M / D D / Y Y) \underline{\mathbf{0 7}} / \underline{\mathbf{2 9}} / \underline{1996}$

\section{B. Bridge Deck Observations}
4. Surface cover... LBUS 6
RBUS 6
LBDS 6
RBDS 6
Overall 6

(2b us,ds,lb,rb: 1- Urban; 2- Suburban; 3- Row crops; 4- Pasture; 5- Shrub- and brushland; 6- Forest; 7- Wetland)
5. Ambient water surface... US $\underline{2}$
UB 2
DS 1
(1- pool; 2- riffle)

6. Bridge structure type 1 (1- single span; 2- multiple span; 3- single arch; 4- multiple arch; 5-cylindrical culvert; 6- box culvert; or 7- other)
7. Bridge length $\mathbf{5 4}$ (feet)
Span length $\underline{\mathbf{5 1}}$
(feet)
Bridge width 19.7 (feet)

\section{Road approach to bridge:}
8. LB 2
RB 2
( 0 even, 1- lower, 2- higher)
9. LB_2
RB $\underline{2}$
(1- Paved, 2- Not paved)

10. Embankment slope (run / rise in feet / foot):

US left

US right

\begin{tabular}{|c|c|c|c|}
\hline \multicolumn{2}{|c|}{ Protection } & \multirow{2}{*}{ 13.Erosion } & 14.Severity \\
\hline 11.Type & 12.Cond. & - & $\mathbf{1}$ \\
\hline $\mathbf{0}$ & - & $\mathbf{2}$ & - \\
\hline $\mathbf{0}$ & - & $\mathbf{0}$ & - \\
\hline $\mathbf{0}$ & - & $\mathbf{0}$ & - \\
\hline $\mathbf{0}$ & - & $\mathbf{2}$ & $\mathbf{1}$ \\
\hline
\end{tabular}

Bank protection types: 0- none; 1- < 12 inches;

2- < 36 inches; 3- < 48 inches;

4- < 60 inches; 5- wall / artificial levee

Bank protection conditions: 1- good; 2- slumped;

3- eroded; 4- failed

Erosion: 0 - none; 1- channel erosion; 2-

road wash; 3- both; 4- other

Erosion Severity: 0 - none; 1- slight; 2- moderate;

\section{Channel approach to bridge (BF):}

15. Angle of approach: $\mathbf{5}$

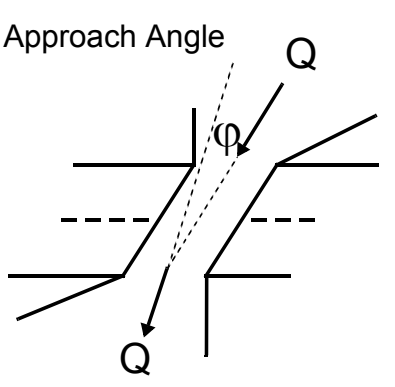

17. Channel impact zone 1 :

Where? LB $(L B, R B)$

Range? 130 feet US

Channel impact zone 2:

Where? RB (LB, RB)

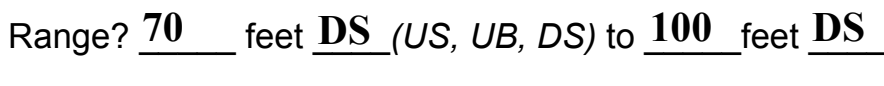

Impact Severity: 0- none to very slight; 1- Slight; 2-Moderate; 3- Severe
16. Bridge skew: 10

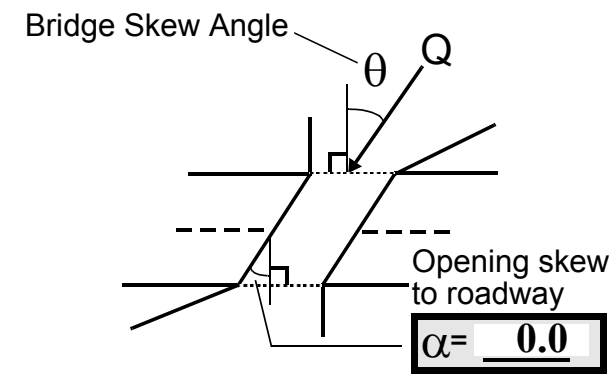

\section{Exist? $\underline{\mathbf{Y}}(\mathrm{Y}$ or $N)$}

Severity 2

(US, UB, DS) to $\underline{\mathbf{8 0}}$ feet $\underline{\mathbf{U S}}$

Exist? $\mathbf{Y}(\mathrm{Y}$ or $N)$

Severity $\underline{0}$ 
18. Bridge Type: 1a

1a- Vertical abutments with wingwalls

$1 \mathrm{~b}$ - Vertical abutments without wingwalls

2- Vertical abutments and wingwalls, sloping embankment Wingwalls parallel to abut. face

3- Spill through abutments

4- Sloping embankment, vertical wingwalls and abutments

Wingwall angle less than $90^{\circ}$.

19. Bridge Deck Comments (surface cover variations, measured bridge and span lengths, bridge type variations, approach overflow width, etc.)

\#4: Surface cover on the right bank upstream and downstream is forest, but there is also a gravel road that runs parallel to the stream.

\#7: Values are from the VTAOT files. Measured bridge length $=53.7$ feet; bridge span $=\mathbf{5 0 . 5}$ feet; and bridge width $=19.9$ feet.

\#11: There is a gully along the road embankment on the upstream left bank.

\section{Upstream Channel Assessment}

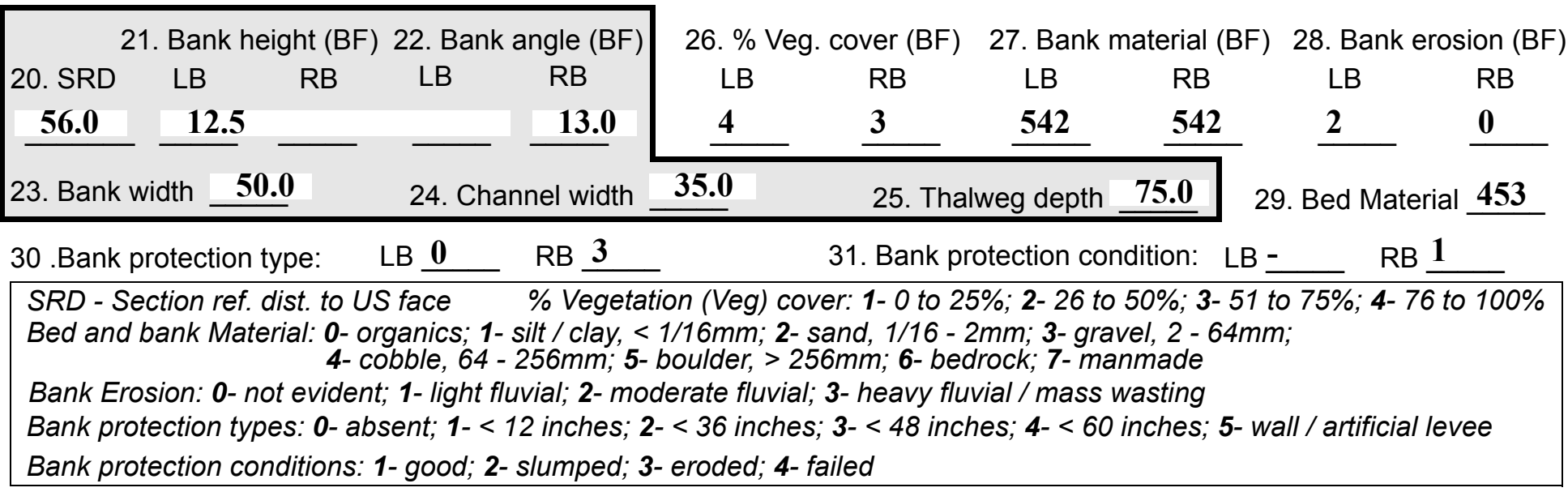

32. Comments (bank material variation, minor inflows, protection extent, etc.):

The left bank is moderately eroded from the bridge to two bridge lengths US.

The right bank is protected by stone fill from 74 feet upstream to the upstream bridge face. The fill also acts as the road embankment protection for TH6. 
36. Point bar extent: $\underline{\mathbf{1 6 0}}$ feet $\underline{\mathrm{US}}$ (US, UB) to $\underline{\mathbf{5 4}}$ feet $\underline{\mathrm{US}}$ (US, UB, DS) positioned $\underline{\mathbf{3 0}} \%$ LB to $\underline{\mathbf{6 0}} \%$ RB

37. Material: 432

38. Point or side bar comments (Circle Point or Side; Note additional bars, material variation, status, etc.):

This is a mid-bar that is vegetated with short grass along the right side.

39. Is a cut-bank present? $\mathbf{Y}$ ( $Y$ or if $N$ type ctrl-n $c b)$

40. Where? LB (LB or RB)

41. Mid-bank distance: 104

42. Cut bank extent: 124 feet $\underline{\mathbf{U S}}$ (US, UB) to $\underline{\mathbf{9 0}}$ feet $\underline{\mathbf{U S}}$ (US, UB, DS)

43. Bank damage: 2

(1- eroded and/or creep; 2- slip failure; 3- block failure)

44. Cut bank comments (eg. additional cut banks, protection condition, etc.):

Most of the flow is pushed left by the mid-bar. A large tree has fallen where the bank has been cut.

Another cut-bank exists on the left bank from 64 feet upstream to 7 feet upstream at the USLWW. The bank is eroded with many exposed roots.

45. Is channel scour present? $\mathbf{N}$ ( $Y$ or if $N$ type ctrl-n cs) 46. Mid-scour distance: -

47. Scour dimensions: Length Width -

Depth : -

Position $\%$ LB to $\% \mathrm{RB}$

48. Scour comments (eg. additional scour areas, local scouring process, etc.):

NO CHANNEL SCOUR

49. Are there major confluences? $\mathbf{N}$

51. Confluence 1: Distance Confluence 2: Distance -

54. Confluence comments (eg. confluence name):

NO MAJOR CONFLUENCES

\section{NO MAJOR CONHLUENCES}

( $Y$ or if $N$ type ctrl-n $m c$ )

52. Enters on -

Enters on ( $L B$ or $R B)$ (LB or $R B)$
50. How many? -

53. Type(1- perennial; 2- ephemeral)

Type (1-perennial; 2- ephemeral)

\section{Under Bridge Channel Assessment}

55. Channel restraint (BF)? LB 2

\begin{tabular}{|ccccc}
\hline \multicolumn{2}{|c}{ 56. Height (BF) } & \multicolumn{3}{c}{57 Angle (BF) } \\
LB & RB & LB & RB \\
48.0 & & & $\mathbf{1 . 5}$ & \\
\hline
\end{tabular}

58. Bank width (BF) (1- natural bank; 2- abutment; 3- artificial levee)

Bed and bank Material: 0- organics; 1- silt / clay, < 1/16mm; 2- sand, 1/16 - 2mm; 3- gravel, 2 - 64mm; 4- cobble, 64 - 256mm; 5- boulder, > 256mm; 6- bedrock; 7- manmade
61. Material (BF)
LB RB
62. Erosion (BF)
$\underline{2} \quad 7$
7

60. Thalweg depth $\lcm{90.0}$

63. Bed Material -

Bank Erosion: 0- not evident; 1- light fluvial; 2- moderate fluvial; 3- heavy fluvial / mass wasting

64. Comments (bank material variation, minor inflows, protection extent, etc.):

5432

The bed material is mostly sand along the abutments. 
65. Debris and Ice Is there debris accumulation?

67. Debris Potential $\underline{\mathbf{1}}$ (1- Low; 2- Moderate; 3- High)

69. Is there evidence of ice build-up? 1

70. Debris and Ice Comments:
$(Y$ or $N)$ 66. Where? $\mathbf{Y}$

68. Capture Efficiency 2

(1- Upstream; 2- At bridge; 3- Both)

Ice Blockage Potential $\mathbf{N}$
(1-Low; 2- Moderate; 3- High)

(1- Low; 2- Moderate; 3- High) 1

\begin{tabular}{|l|c|c|c|c|c|c|c|c|}
\hline Abutments & $\begin{array}{c}\text { 71. Attack } \\
\angle \text { (BF) }\end{array}$ & $\begin{array}{c}\text { 72. Slope } \angle \\
\text { (Qmax) }\end{array}$ & $\begin{array}{c}\text { 73. Toe } \\
\text { loc. (BF) }\end{array}$ & $\begin{array}{c}\text { 74. Scour } \\
\text { Condition }\end{array}$ & $\begin{array}{c}75 . \text { Scour } \\
\text { depth }\end{array}$ & $\begin{array}{c}\text { 76. Exposure } \\
\text { depth }\end{array}$ & 77. Material & 78. Length \\
\hline LABUT & & - & $\mathbf{9 0}$ & $\mathbf{2}$ & $\mathbf{3}$ & $\mathbf{0}$ & $\mathbf{4 . 2 5}$ & $\mathbf{9 0 . 0}$ \\
\hline RABUT & $\mathbf{1}$ & $\mathbf{1 0}$ & $\mathbf{9 0}$ & & & $\mathbf{2}$ & $\mathbf{2}$ & $\mathbf{4 8 . 5}$ \\
\hline
\end{tabular}

Pushed: $L B$ or RB

Toe Location (Loc.): 0- even, 1- set back, 2- protrudes

Scour cond.: 0- not evident; 1- evident (comment); 2- footing exposed; 3-undermined footing; 4- piling exposed; 5- settled; 6- failed

Materials: 1- Concrete; 2- Stone masonry or drywall; 3- steel or metal; 4- wood

79. Abutment comments (eg. undermined penetration, unusual scour processes, debris, etc.):

0

3

1

The left abutment is undermined 0.5 feet at the upstream corner where it joins the wingwall. There is a subfooting on the left abutment that starts at the upstream end and widens at the downstream end. The subfooting is $\mathbf{1 . 5}$ feet thick and the footing is $\mathbf{2}$ feet thick.

On the right abutment, there is a narrow footing that is exposed 3 feet in the center of the abutment wall, and then the banks angle up to the protection on both upstream and downstream ends.

80. Wingwalls:

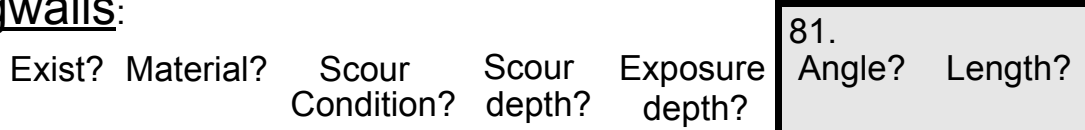

USLWW:

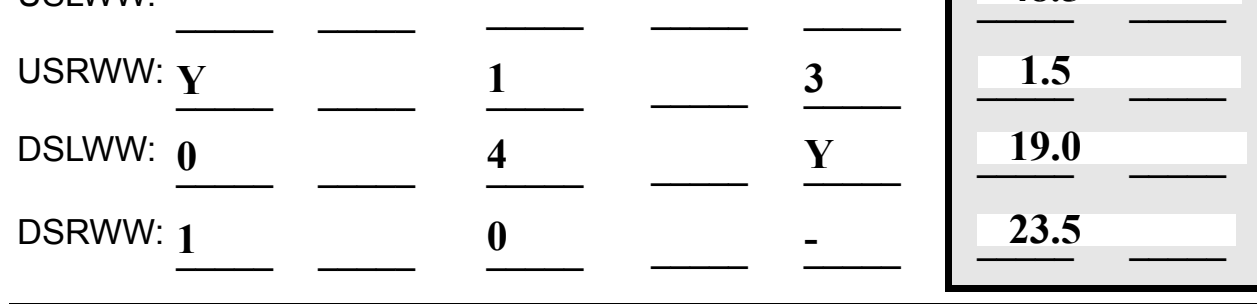

Wingwall materials: 1- Concrete; 2- Stone masonry or drywall; 3- steel or metal; 4- wood

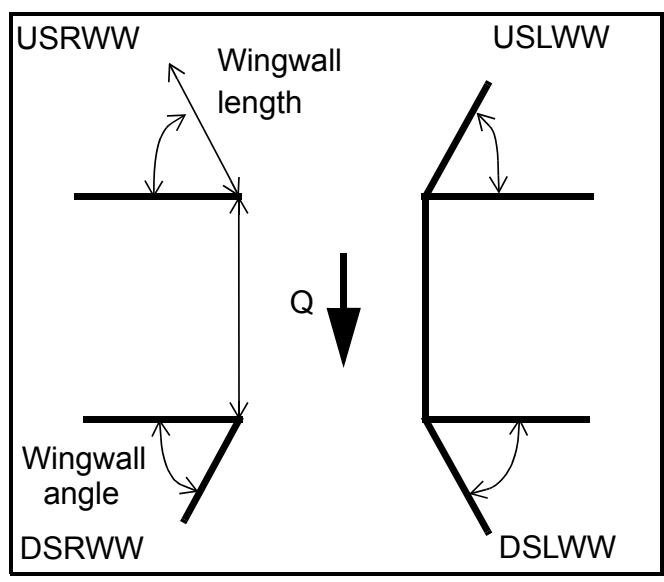

82. Bank / Bridge Protection:

\begin{tabular}{|l|l|l|l|l|l|l|c|c|}
\hline Location & USLWW & USRWW & LABUT & RABUT & LB & RB & DSLWW & DSRWW \\
\hline Type & - & $\mathbf{2}$ & Y & - & - & $\mathbf{1}$ & - & - \\
\hline Condition & $\mathbf{Y}$ & $\mathbf{0}$ & $\mathbf{1}$ & - & - & $\mathbf{1}$ & - & - \\
\hline Extent & $\mathbf{1}$ & $\mathbf{2 . 2 5}$ & $\mathbf{0}$ & $\mathbf{0}$ & $\mathbf{3}$ & $\mathbf{0}$ & $\mathbf{0}$ & - \\
\hline
\end{tabular}

Bank / Bridge protection types: 0- absent; 1- < 12 inches; 2- < 36 inches; 3- < 48 inches; 4- < 60 inches; 
83. Wingwall and protection comments (eg. undermined penetration, unusual scour processes, etc.):

-
-
-
-
-
0
-
-
3
1
1

\section{Piers:}

84. Are there piers? US (Y or if $N$ type ctrl-n pr)

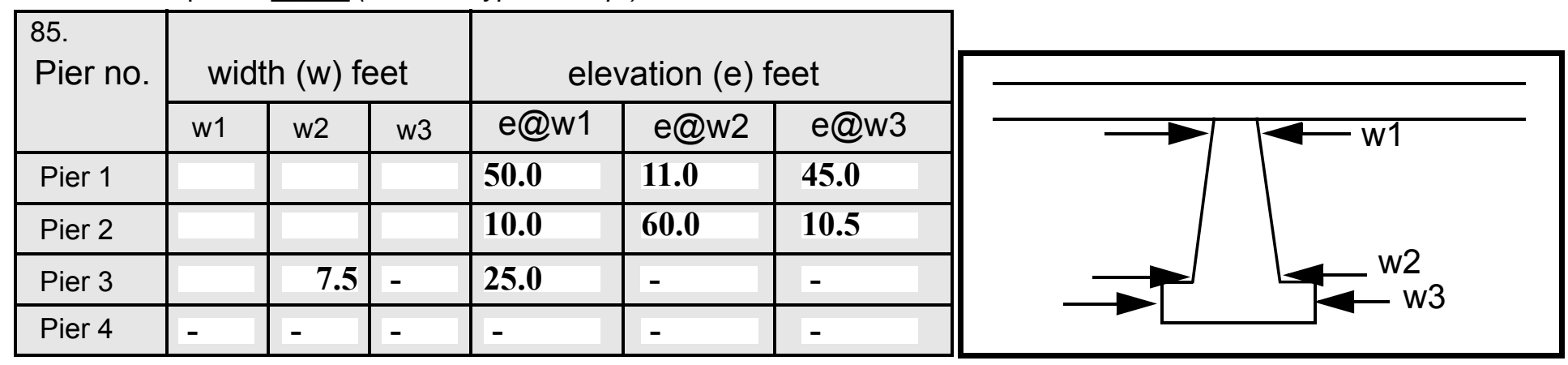

\begin{tabular}{|l|l|l|l|l|}
\hline Level 1 Pier Descr. & \multicolumn{1}{|c|}{1} & \multicolumn{1}{|c|}{2} & \multicolumn{1}{|c|}{3} & \multicolumn{1}{|c|}{4} \\
\hline 86. Location (BF) & RWW & bank & sed & feet at \\
\hline 87. Type & and & pro- & foot- & the \\
\hline 88. Material & DSR & tec- & ings. & cor- \\
\hline 89. Shape & WW & tion. & The & ner \\
\hline 90. Inclined? & pro- & The & USL & with \\
\hline 91. Attack $\angle$ (BF) & tec- & USL & WW & the \\
\hline 92. Pushed & tion & WW & is & LAB \\
\hline 93. Length (feet) & - & - & - & - \\
\hline 94. \# of piles & is & and & also & UT. \\
\hline 95. Cross-members & same & DSL & unde & Ther \\
\hline 96. Scour Condition & as & WW & rmin & e is \\
\hline 97. Scour depth & the & have & ed & no \\
\hline 98. Exposure depth & right & expo & 0.5 & sub- \\
\hline
\end{tabular}

LFP, LTB, LB, MCL, MCM, MCR, RB, RTB, RFP

1- Solid pier, 2- column, 3- bent

1-Wood; 2- concrete; 3- metal; 4- stone

1- Round; 2- Square; 3- Pointed

Y-yes; $N-$ no

$L B$ or $R B$

0- none; 1- laterals; 2- diagonals; 3- both

0- not evident; 1- evident (comment);

2- footing exposed; 3- piling exposed;

4- undermined footing; 5- settled; 6- failed 
99. Pier comments (eg. undermined penetration, protection and protection extent, unusual scour processes, etc.):

footing here and the footing is $\mathbf{3 . 5}$ feet thick. At the downstream end, only the top of the subfooting is visible and the footing is $\mathbf{2 . 2 5}$ feet thick for the DSLWW.

$\mathbf{N}$

100.

\section{E. Downstream Channel Assessment}

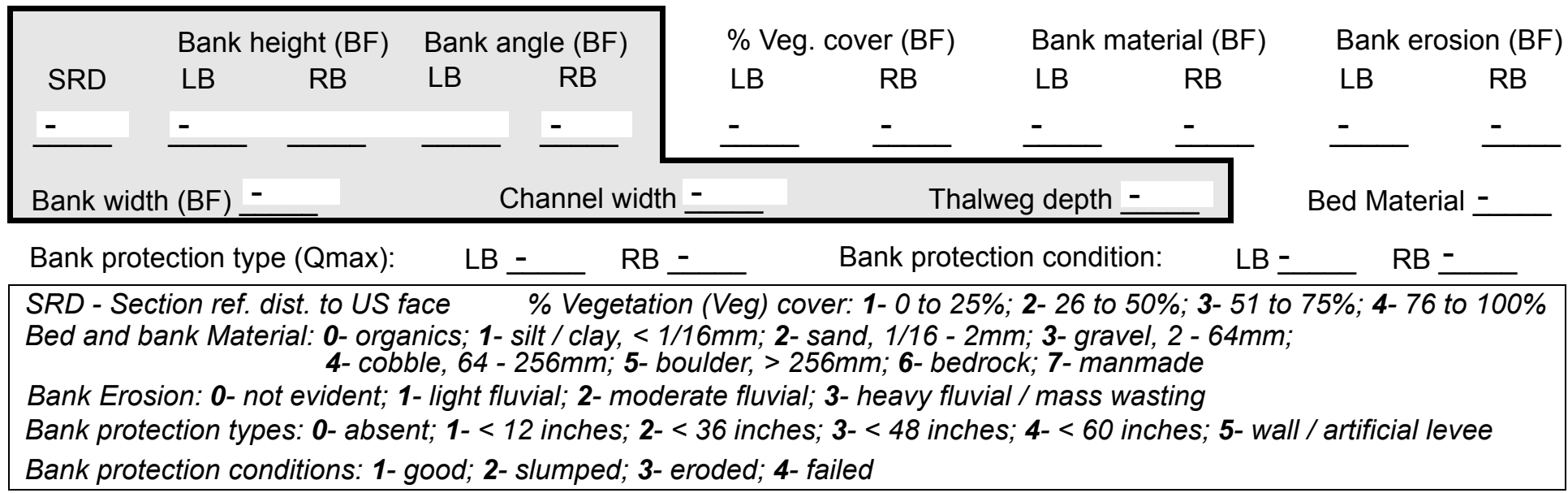

Comments (eg. bank material variation, minor inflows, protection extent, etc.):

$-$

$-$

-

-

-

-

-

-

-

-

-

-

-

-

101. Is a drop structure present? _ ( $Y$ or $N$, if $N$ type ctrl-n ds) 102. Distance: ___ feet
103. Drop: - feet
104. Structure material: -
(1- steel sheet pile; 2- wood pile; 3- concrete; 4- other)

105. Drop structure comments (eg. downstream scour depth):

$-$

-

-

- 
106. Point/Side bar present? (Y or $N$. if $N$ type ctrl-n pb)Mid-bar distance:

Mid-bar width: -

Point bar extent: feet -

(US, UB, DS) to feet (US, UB, DS) positioned \%LB to $\%$ RB Material:

Point or side bar comments (Circle Point or Side; note additional bars, material variation, status, etc.):

$-$

$-$

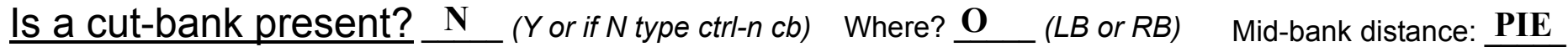
Cut bank extent: $\underline{\mathbf{R S}}$ feet __ (US, UB, DS) to feet ___ (US, UB, DS)

Bank damage: (1- eroded and/or creep; 2- slip failure; 3- block failure)

Cut bank comments (eg. additional cut banks, protection condition, etc.):

Is channel scour present? ( $Y$ or if $N$ type ctrl-n cs)

Mid-scour distance: $\underline{\mathbf{3}}$ Scour dimensions: Length 3 Width 234 Depth: 234

Positioned 0 \%LB to $\mathbf{0}$ $\% \mathrm{RB}$ Scour comments (eg. additional scour areas, local scouring process, etc.): 432

0

3

$-$

Are there major confluences? 1 ( 1 or if $N$ type ctrl-n $m c)$ Confluence 1: Distance bed Confluence 2: Distance is Enters on mat (LB or RB) How many? The Confluence comments (eg. confluence name):

Enters on mos (LB or RB) Type erial (1- perennial; 2- ephemeral) Type tly (1-perennial; 2- ephemeral) sand along the banks.

\section{F. Geomorphic Channel Assessment}

107. Stage of reach evolution

1- Constructed

2- Stable

3- Aggraded

4- Degraded

5- Laterally unstable

6- Vertically and laterally unstable 
108. Evolution comments (Channel evolution not considering bridge effects; See HEC-20, Figure 1 for geomorphic descriptors):

nk protection on the right bank extends from the downstream bridge face to 49 feet downstream. 


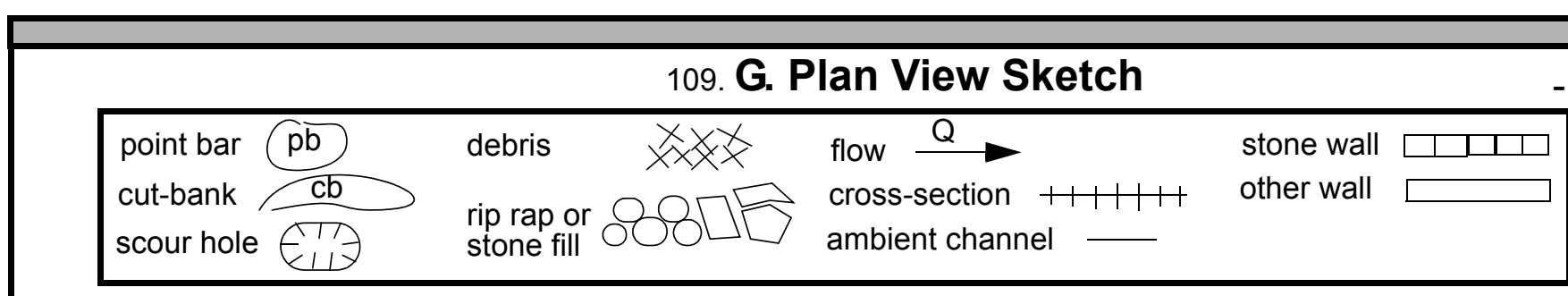


APPENDIX F:

SCOUR COMPUTATIONS 


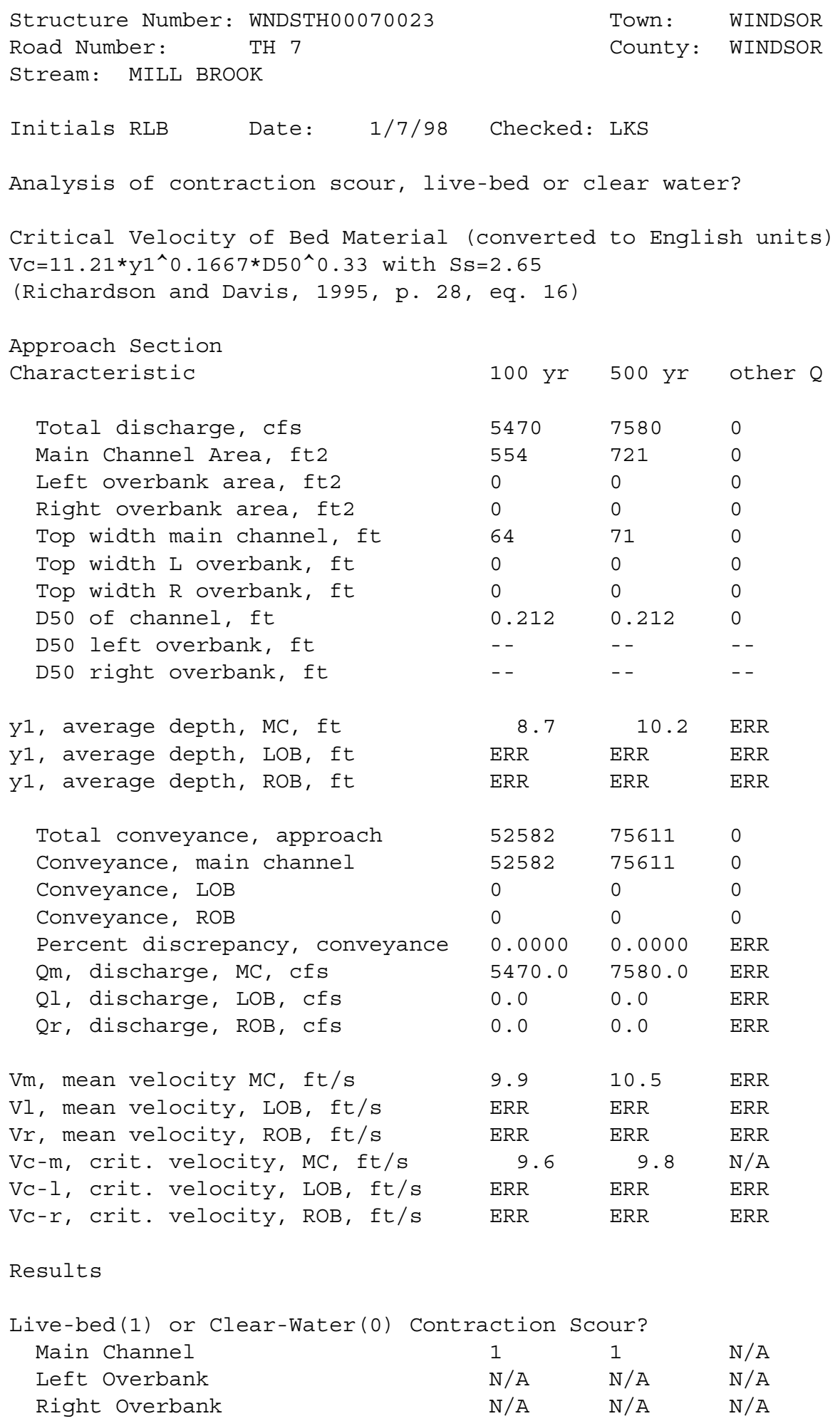




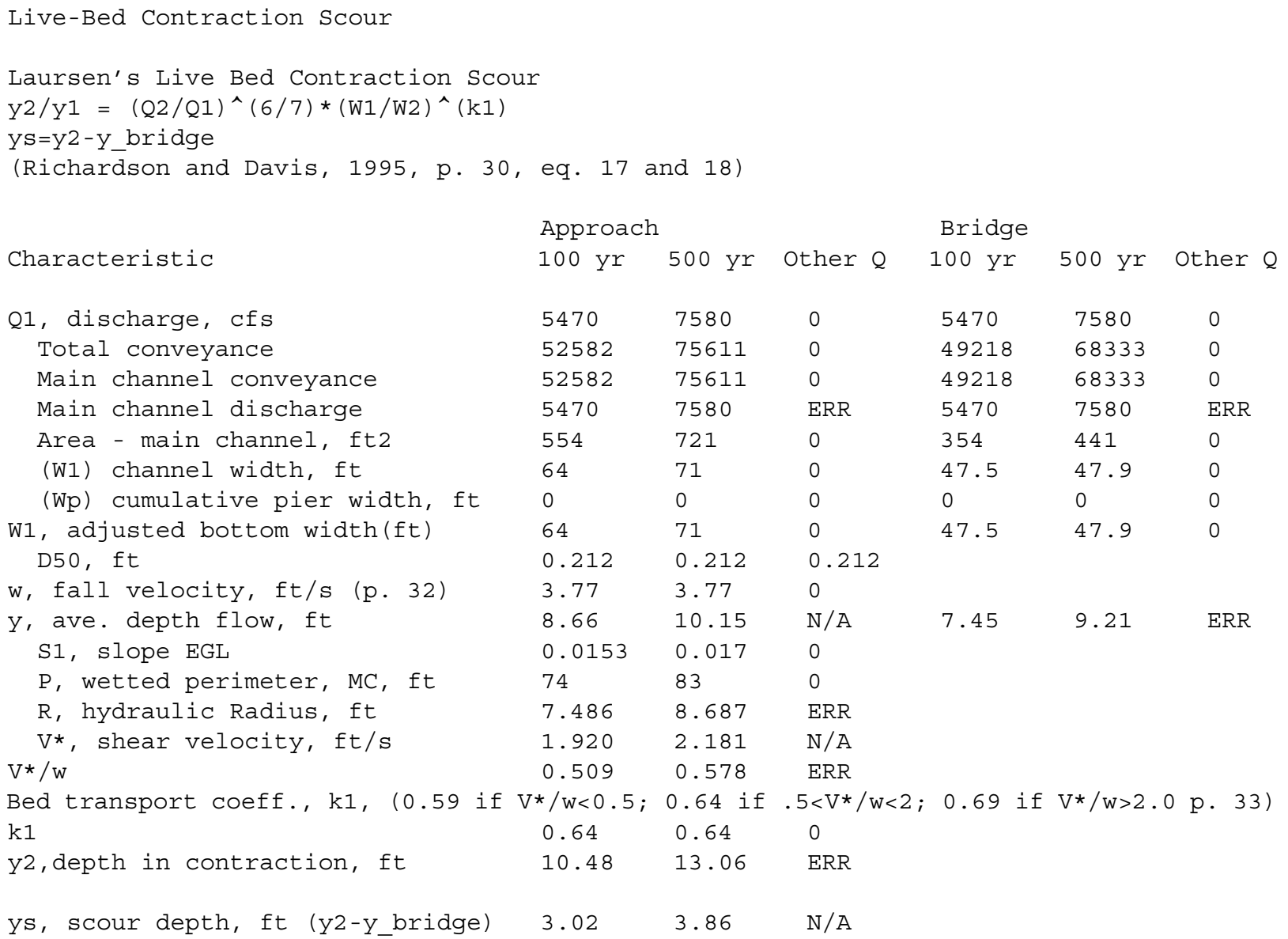

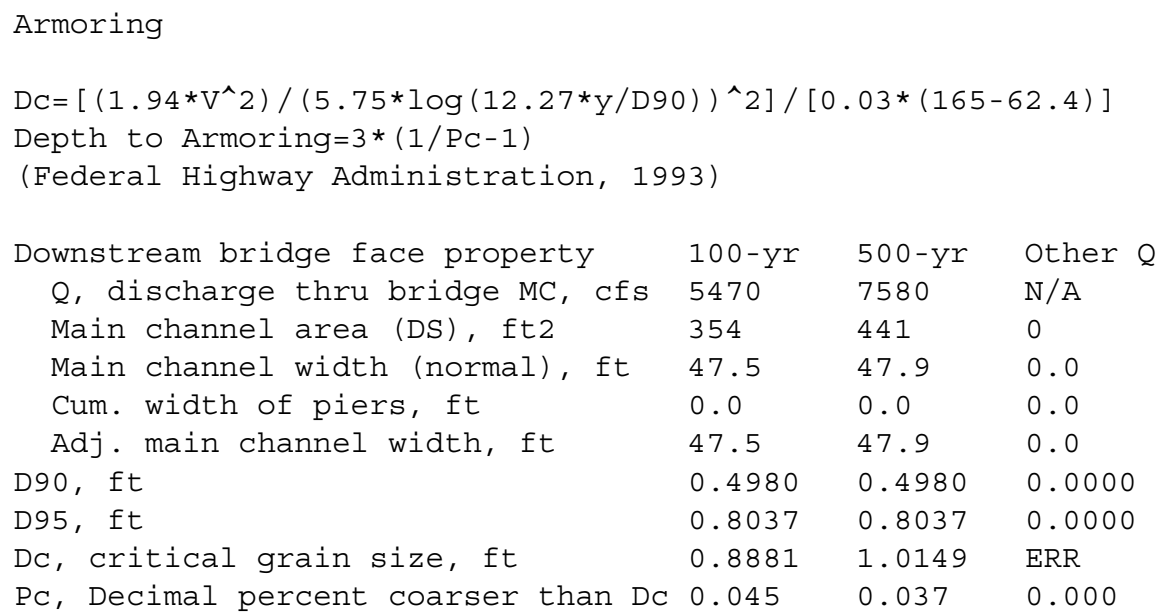


Abutment scour

Froehlich's Abutment Scour

$\mathrm{Ys} / \mathrm{Y} 1=2.27 * \mathrm{~K} 1 * \mathrm{~K} 2 *\left(\mathrm{a}^{\prime} / \mathrm{Y} 1\right) \wedge 0.43 * \mathrm{Fr} 1 \wedge 0.61+1$

(Richardson and Davis, 1995, p. 48, eq. 28)

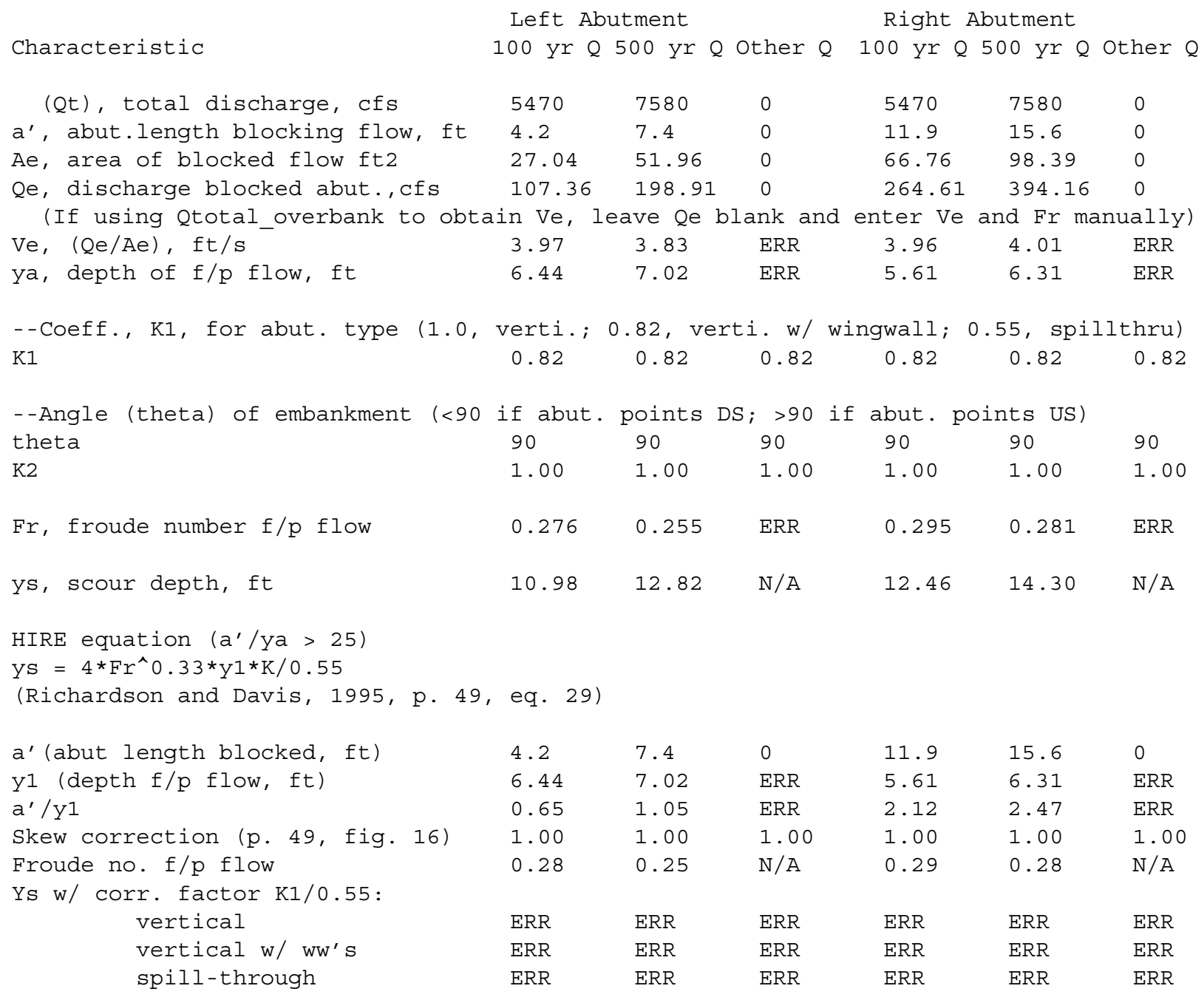




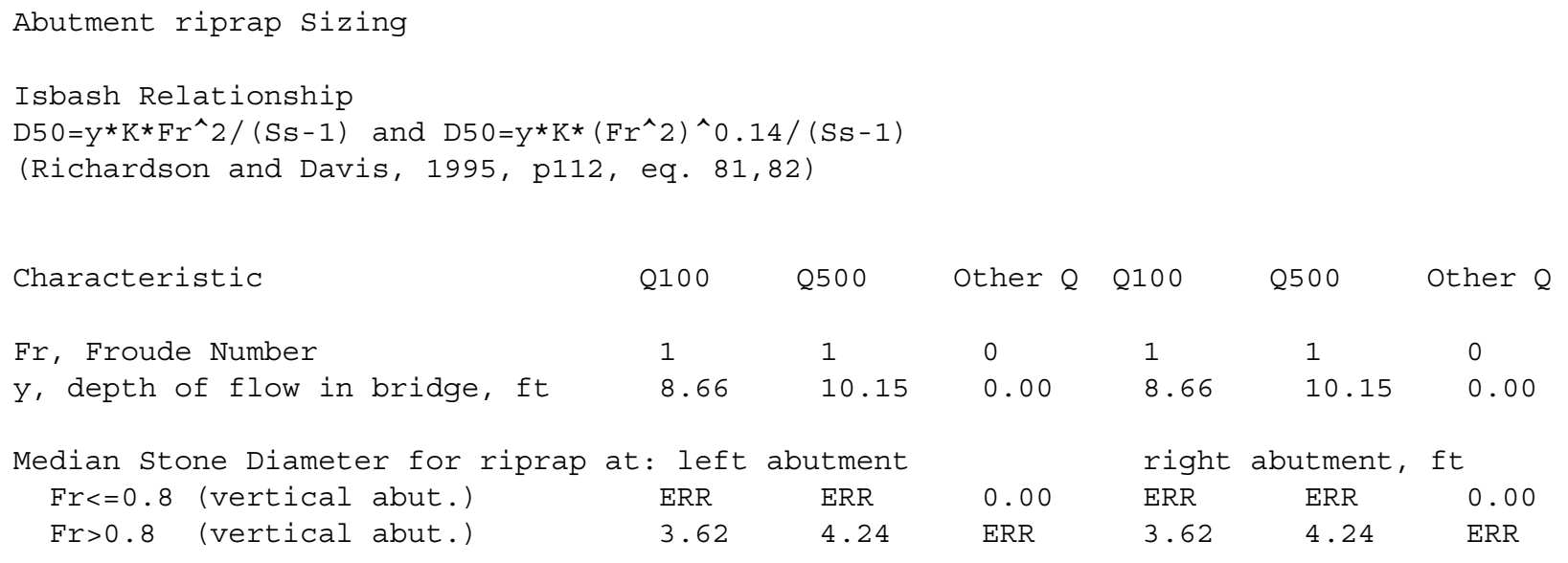

